\title{
Histopathology of Prostate Cancer
}

\author{
Peter A. Humphrey \\ Department of Pathology, Yale University School of Medicine, New Haven, Connecticut 06437 \\ Correspondence: peter.humphrey@yale.edu
}

This review focuses on histopathological aspects of carcinoma of the prostate. A tissue diagnosis of adenocarcinoma is often essential for establishing a diagnosis of prostate cancer, and the foundation for a tissue diagnosis is currently light microscopic examination of hematoxylin and eosin (H\&E)-stained tissue sections. Markers detected by immunohistochemistry on tissue sections can support a diagnosis of adenocarcinoma that is primary in the prostate gland or metastatic. Histological variants of carcinoma of the prostate are important for diagnostic recognition of cancer or as clinicopathologic entities that have prognostic and/ or therapeutic significance. Histological grading of adenocarcinoma of the prostate, including use of the 2014 International Society of Urological Pathology (ISUP) modified Gleason grades and the new grade groups, is one of the most powerful prognostic indicators for clinically localized prostate cancer, and is one of the most critical factors in determination of management of these patients.

Establishment of a histopathological diagnoEsis of prostate cancer requires light microscopic examination of hematoxylin and eosin (H\&E)-stained tissue sections. The most common prostatic parenchymal tissue samples examined in surgical pathology laboratories in the United States are, in order, 18-gauge needle cores, transurethral resections, radical prostatectomy specimens, open (simple or enucleation) prostatectomy specimens (uncommon), and fine-needle aspirates (rare). Needle core biopsies and fine needle aspirates may be used to diagnose metastatic prostate cancer.

Prostate cancer indicates a malignant neoplasm of the prostate. The vast majority of these malignant neoplasms are of epithelial origin and differentiation, and are carcinomas. These carcinomas are the subject of this review. There are rare malignant neoplasms in the prostate such as malignant mesenchymal neoplasms (sarcomas) and hematolymphoid neoplasms (lymphomas) of the prostate (Humphrey 2003a; Cheville et al. 2016; Ferry 2016); these nonepithelial neoplasms are not discussed here.

This review will focus on diagnostic histopathological and immunophenotypic attributes of prostatic carcinoma, including intraductal carcinoma, invasive adenocarcinoma, variants of prostatic carcinoma, and effects of treatment of prostatic carcinoma. Histopathological grading will also be presented.

\section{INTRADUCTAL CARCINOMA}

Intraductal carcinoma of the prostate is defined as an intra-acinar and/or intraductal neoplastic epithelial proliferation that fills large acini and prostatic ducts, with preservation of basal cells,

Editors: Michael M. Shen and Mark A. Rubin

Additional Perspectives on Prostate Cancer available at www.perspectivesinmedicine.org

Copyright (C) 2017 Cold Spring Harbor Laboratory Press; all rights reserved; doi: 10.1101/cshperspect.a030411

Cite this article as Cold Spring Harb Perspect Med 2017;7:a030411 
P.A. Humphrey

and with formation of either solid or dense cribriform patterns, or a loose or micropapillary pattern with either marked nuclear atypia (with nuclear size $6 \times$ normal or larger) or comedonecrosis (Guo and Epstein 2006; Robinson et al. 2012; Epstein et al. 2016c). This entity is seen in $\sim 3 \%$ of needle core cases and $17 \%$ to $40 \%$ of radical prostatectomy cases; in these cases, it is typically admixed with invasive adenocarcinoma (McNeal and Yemoto 1996; Watts et al. 2013; Miyai et al. 2014). Only rarely is intraductal carcinoma detected in isolated form, without invasive adenocarcinoma, being diagnosed in $0.1 \%$ to $0.3 \%$ of needle core cases (Guo and Epstein 2006; Robinson et al. 2012; Watts et al. 2013).

Intraductal carcinoma is thought to represent a late event in prostate cancer evolution, and is typically associated with high-grade and high-stage invasive adenocarcinoma (Robinson and Epstein 2010). A current view is that most cases of intraductal carcinoma represent spread of invasive high-grade carcinoma into preexisting ducts and acini (Haffner et al. 2016). In a minority of cases, intraductal carcinoma could serve as a precursor proliferation (Miyai et al. 2014).

The main differential diagnostic considerations are high-grade prostatic intraepithelial neoplasia (PIN) and invasive but circumscribed high-grade prostatic acinar adenocarcinoma with cribriform or solid patterns (Wobker and Epstein 2016), as well as urothelial carcinoma with intraductal growth, and the intraductal component of ductal adenocarcinoma. Immunohistochemistry may be of use in addressing the differential diagnosis in selected cases. Loss of cytoplasmic PTEN expression favors intraductal carcinoma over high-grade PIN (Lotan et al. 2013; Morais et al. 2015) and complete absence of basal cells (as found with immunostains for p63 and/or high molecular weight cytokeratins) is indicative of invasive carcinoma rather than intraductal carcinoma. The prostate markers PSA, PSAP, prostein (P501S), and NKX3.1 will be positive in intraductal carcinoma, whereas GATA3, p63, and high-molecularweight cytokeratin (detected by $34 \beta \mathrm{E} 12$ antibody binding) expression in neoplastic cells would be consistent with intraductal urothelial carcinoma. Ductal adenocarcinoma often has an intraductal component and these neoplastic cells are more often columnar in shape and pseudostratified with papillary architecture, compared with intraductal acinar carcinoma cells, but there may be overlap in their appearances.

Intraductal carcinoma is not assigned a Gleason grade (Epstein et al. 2016c). Intraductal carcinoma is linked to aggressive prostate cancer, as assessed by both pathologic and clinical outcome endpoints. It is usually associated with high-grade and high-volume carcinoma with a median Gleason score of 8 and T3 pathologic stage, with increased risk of extraprostatic extension, seminal vesicle invasion, and pelvic lymph node metastases (Robinson and Epstein 2010; Divatia and Ro 2016). The presence of intraductal carcinoma in needle biopsy tissue and transurethral resections is an independent indicator of early biochemical relapse and metastatic failure rate after radiation therapy (van der Kwast et al. 2012) and is associated with disease-specific survival (Kweldam et al. 2016). Intraductal carcinoma in radical prostatectomy tissue has been shown be an independent indicator of survival (Kimura et al. 2014) and to improve the capacity of nomograms to predict biochemical failure after surgery (O'Brien et al. 2011).

The diagnosis of isolated intraductal carcinoma in prostate needle biopsy tissue may prompt definitive treatment, although $10 \%$ of patients will have isolated intraductal carcinoma without invasive disease in the whole gland after radical prostatectomy (Robinson and Epstein 2010), such that rebiopsy may be also be an option.

\section{INVASIVE ADENOCARCINOMA}

\section{Major and Minor Diagnostic Criteria}

The foundation for the histologic diagnosis of adenocarcinoma of the prostate is the assessment for the three major criteria of glandular architecture, loss of basal cells, and nuclear features of the glandular lining cells (Table 1) (Totten et al. 1953; Mostofi et al. 1993; Humphrey et al. 2016a). 
Table 1. Criteria for diagnosis of prostatic adenocarcinoma

Major criteria
Architectural: Infiltrative small glands or cribriform
glands too large or irregular to represent high-
grade prostatic intraepithelial neoplasia (PIN)
Single-cell layer (absence of basal cells)
Nuclear atypia: nuclear and nucleolar enlargement
Minor criteria
Intraluminal wispy blue mucin (blue-tinged or
basophilic mucinous secretions)
Pink amorphous secretions
Mitotic figures
Intraluminal crystalloids
Adjacent high-grade PIN
Amphophilic cytoplasm

Prostatic adenocarcinoma displays an abnormal architectural glandular pattern with disturbance of benign epithelial-stromal relationships. These alterations are best appreciated at low-power scanning magnifications. Many of the common growth patterns of prostatic adenocarcinoma are well illustrated by the International Society of Urological Pathology (ISUP) 2015 modified Gleason grading schematic diagram (Fig. 1), which presents five patterns of growth (Epstein et al. 2016b). The lowest grades, comprised of Gleason patterns 1 through 3 , form grade group 1 in the new grade group scheme (Table 2). These malignant glands are single, separate, and well formed (Fig. 2). They may be crowded and nodular, as seen in Gleason patterns 1 and 2, which are characteristically detected in the transition zone. Gleason pattern 3 glands may be crowded or the glands may be haphazardly arranged and infiltrative into stroma (Fig. 2). The infiltration may be recognized as growth in between (Fig. 2) and around benign glands. Stromal infiltration is also seen in high-grade Gleason patterns 4 and 5 (and grade groups 2 to 5). Effacement of normal prostatic microanatomy with destruction of benign prostatic tissue and replacement by malignant glands can be observed with all grades. High-grade Gleason pattern 4 adenocarcinoma glands are cribriform (Fig. 3), poorly formed, fused, or glomeruloid (Fig. 1). Highgrade Gleason pattern 5 adenocarcinoma consists of sheets of tumor (Fig. 4), individual cells, cords, linear arrays, and solid nests (Fig.1) (Gottipati et al. 2012; Epstein et al. 2016b; Humphrey et al. 2016a). A host response to stromal infiltration by adenocarcinoma, including a fibrogenic response and inflammatory response, is not usually evident on H\&E-stained tissue sections. Uncommonly, there can be a sclerotic response to the invading glands. An inflammatory response is unusual, being seen in $\sim 10 \%$ of cases, and is usually lymphocytic. Also uncommon are acutely inflamed carcinoma glands, which usually show intraluminal neutrophils.

Loss of basal cells is the second major defining attribute of invasive adenocarcinoma. Normal basal cells separate secretory luminal cells from the basement membrane. They frequently appear as rounded or oblong cells with small hyperchromatic nuclei and scant cytoplasm.

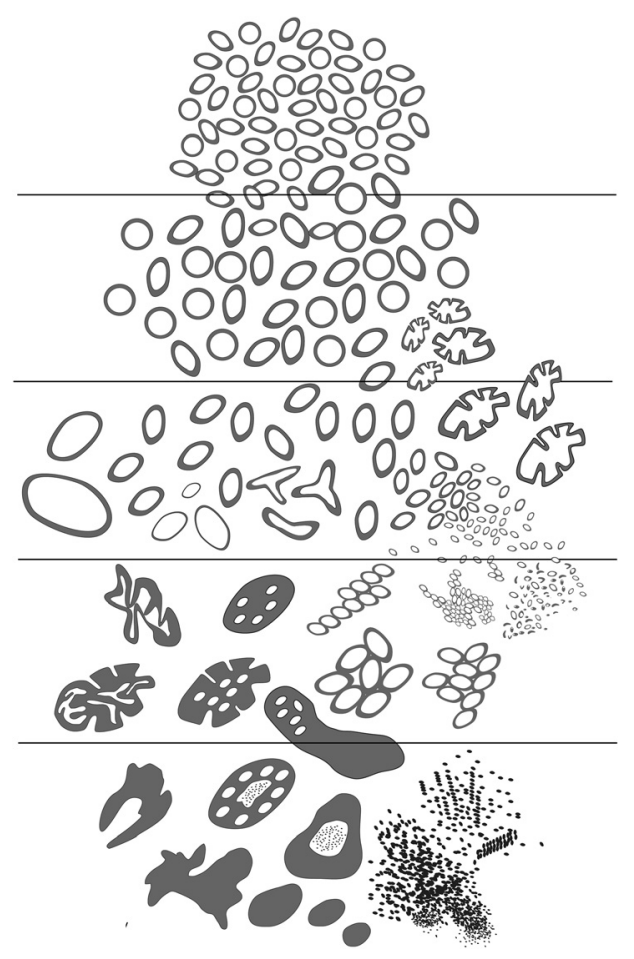

Figure 1. Prostate cancer grades. 2015 modified Gleason grading schematic diagram according to the International Society of Urological Pathology (ISUP). Grade patterns 1 (top) through 5 (bottom). (From Humphrey et al. 2016a; reprinted, with permission.) 
P.A. Humphrey

Table 2. Grade groups

Grade group 1: Gleason score $\leq 6$

Only individual discrete well-formed glands

Grade group 2: Gleason score $3+4=7$

Predominantly well-formed glands with lesser component of poorly formed/fused/cribriform glands

Grade group 3: Gleason score $4+3=7$

Predominantly poorly formed/fused/cribriform glands with lesser ( $>5 \%)$ component of well-formed glands

Grade group 4: Gleason score $4+4=8 ; 3+5=8$; or $5+3=8$

Only poorly formed/fused/cribriform glands, or

Predominantly well-formed glands and lesser component lacking glands, or

Predominantly lacking glands and lesser component of well-formed glands

Grade group 5: Gleason scores 9-10

Lack gland formation (or with necrosis) with or without poorly formed/fused/cribriform glands

From Epstein et al. (2016b).

Basal cells in prostatic glands may, however, be difficult to distinguish from periglandular fibroblasts and myofibroblasts, based on examination of H\&E-stained sections. Furthermore, prostatic adenocarcinoma cells that are in thick histologic sections, are poorly fixed and preserved, and are distorted or crushed, may mimic basal cells. In diagnostically challenging situations, such as the diagnosis of small foci of adenocarcinoma (limited or minimal adenocarcinoma in needle biopsy tissue) or deceptively benign-appearing adenocarcinomas, immunohistochemistry to detect basal cell-specific proteins can be extremely useful (Hameed and Humphrey 2005; Epstein et al. 2014b). Basal cell loss is not absolutely specific for invasive adenocarcinoma, because some benign glands may lack basal cells (see section below on basal cell immunohistochemistry).

Nuclear atypia in the form of nuclear enlargement and nucleolar enlargement is the third of the major criteria. Nuclear atypia in malignant glands is most often manifested as nuclear enlargement and prominent nucleoli. A classical appearance of a prostatic carcinoma nucleus is a single large nucleus with chromatin clearing and a deeply staining macronucleolus. Although macronucleoli are characteristic of prostatic carcinoma, not all prostatic carcinomas harbor prominent nucleoli. How to define "prominence" is a matter of some debate and nucleoli with a diameter from $1 \mu \mathrm{m}$ to $3 \mu \mathrm{m}$ or greater have been deemed prominent in the past. In one study of limited carcinoma in needle biopsy, fully one quarter of the cases lacked prominent nucleoli (Epstein 1995). Additional carcinomas that may have small nuclei without prominent nucleoli include foamy gland carcinoma (Humphrey 2012) and carcinomas with androgen deprivation or radiation therapy effect (Srigley et al. 2012).

Minor, ancillary criteria can be helpful in diagnosing prostatic adenocarcinoma (Table 1). These minor characteristics are not specific for carcinoma but are useful in prompting in-depth study of the glands harboring these changes with a view to assessment of the above-discussed major diagnostic criteria. They include intraluminal mucin, pink amor-

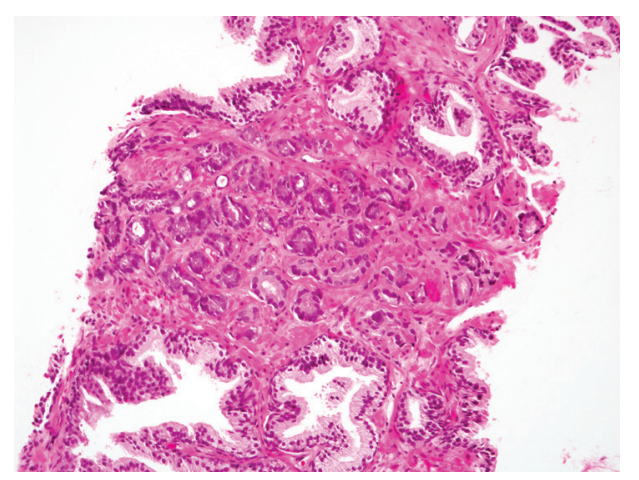

Figure 2. Adenocarcinoma of the prostate, Gleason grade $3+3=$ score of 6 (grade group 1), with single, separate, well-formed glands in needle core biopsy from prostate. 


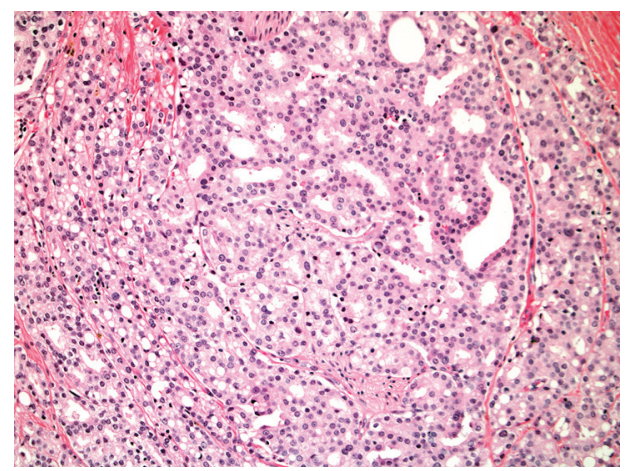

Figure 3. Adenocarcinoma of the prostate, Gleason grade $4+4=$ score of 8 (grade group 4 ), with cribriform and fused glands in needle core biopsy from prostate.

phous intraluminal secretions, mitotic figures, cystalloids, and amphophilic cytoplasm.

Intraluminal wispy blue mucin identified on H\&E-stained sections is more often found in carcinoma than in benign epithelial proliferations (Epstein 1995; Kaleem et al. 1998; Varma et al. 2002). The incidence in adenocarcinoma ranges from $18 \%$ to $34 \%$ in small foci in needle biopsies (Epstein 1995) to $72 \%$ in whole prostate glands at radical prostatectomy (Kaleem et al. 1998). This wispy blue mucin corresponds to acidic mucin, as substantiated by Alcian blue histochemical staining at $\mathrm{pH}$ 2.5. It is not specific for carcinoma by $\mathrm{H} \& \mathrm{E}$ or Alcian blue staining and can be recognized in mucinous metaplasia, atrophy, basal cell hyperplasia, sclerosing adenosis, atypical adenomatous hyperplasia (adenosis), and PIN.

Pink amorphous intraluminal secretions are also encountered more often in malignant than in benign glands (Epstein 1995; Kaleem et al. 1998; Thorson et al. 1998; Varma et al. 2002).

These secretions are found in $53 \%-92 \%$ of adenocarcinomas in needle biopsy and in 84\% of adenocarcinomas in the whole gland. They can be observed in a majority of high-grade PIN cases. They are discerned in only $2 \%-3 \%$ of benign glands, including $3 \%$ of benign atrophic glands. Scattered nuclear debris within the eosinophilic secretions should not be misinterpreted as necrotic tumor debris of comedocarcinoma.
Mitotic figures are an atypical finding in prostatic epithelium, with a trend toward an increased frequency in glands of carcinoma, being detectable in $0.001 \%$ of cells in benign glands versus $0.1 \%$ of cells in high-grade PIN versus $0.06 \%-0.15 \%$ of adenocarcinoma cells (Giannulis et al. 1993). Mitotic figures can be identified in $2 \%-11 \%$ of cases of minimal adenocarcinoma in needle biopsy and 38\% of cases of adenocarcinoma in the whole gland (Epstein 1995; Kaleem et al. 1998; Thorson et al. 1998). Mitotic figures are not specific for adenocarcinoma and can occur in benign epithelium, especially adjacent to infarcts. The discovery of atypical mitotic figures is vanishingly rare in primary prostatic carcinoma, except in Gleason pattern 5 or neuroendocrine carcinoma. The diagnostic use of mitoses is diminished because of the lack of specificity, the more common occurrence in readily diagnosed higher-grade carcinoma, and the fact that most prostatic carcinomas in needle biopsy do not harbor mitotic figures.

Prostatic crystalloids are intraluminal, brightly eosinophilic, nonbirefringent structures that often assume geometric shapes such as needle-like, triangular, and hexagonal configurations (Jensen et al. 1980; Ro et al. 1986; Henneberry et al. 1997). They are found more often in adenocarcinoma than in benign glands. The incidence of crystalloids in adenocarcinoma is dependent on the extent of sampling and

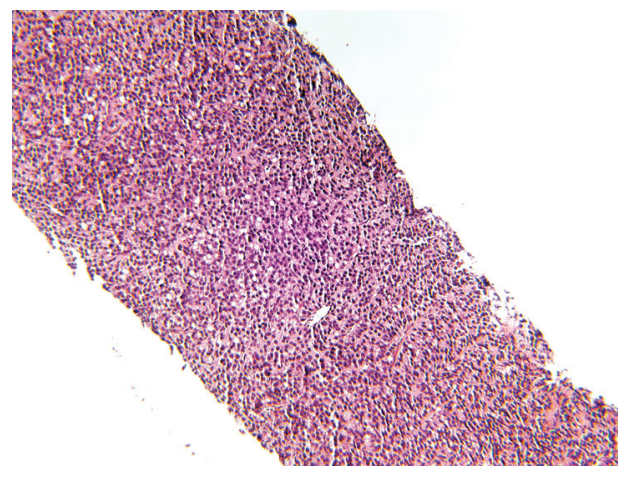

Figure 4. Adenocarcinoma of the prostate, Gleason grade $5+5=$ score of 10 (grade group 5 ), with solid sheet-like growth in needle core biopsy from prostate. 
P.A. Humphrey

the histological grade of the adenocarcinoma, with the highest likelihood of detection in the lowest Gleason patterns 1 to 3 (Ro et al. 1986; Epstein 1995). Crystalloids are rarely found in high-grade Gleason pattern 4 or 5 adenocarcinomas. Crystalloids should be distinguished from intraluminal corpora amylacea, which are concentrically lamellated bodies that are, conversely, more often seen in benign $(78 \%$ of cases) than in carcinomatous glands $(11 \%-$ $13 \%$ of cases in the whole gland and $<1 \%$ in needle cores) (Humphrey and Vollmer 1990; Christian et al. 2005). Diagnostically, the prime advantage to the detection of crystalloids is to direct further scrutiny of the glands that contain the crystalloids.

The appearance of the cytoplasm in prostatic epithelial cells is of only slight assistance in the diagnosis of carcinoma. An amphophilic cytoplasm is more often present in carcinoma cells than in benign glandular cells, which tend to have a granular cleared cytoplasm. However, this is not specific and a cleared cytoplasm is common in low-grade Gleason pattern 1 and 2 prostatic adenocarcinomas. Furthermore, benign glands can have amphophilic cytoplasm in an appreciable number of cases. As for sensitivity, $36 \%-60 \%$ of prostatic carcinomas in needle biopsy and up to $100 \%$ of carcinomas in radical prostatectomy specimens have amphophilic cytoplasm (Epstein 1995; Kaleem et al. 1998; Thorson et al. 1998). In addition to being amphophilic or cleared, prostatic carcinoma cytoplasm can uncommonly reveal Panethcell-like neuroendocrine differentiation (Adlakha and Bostwick 1994; Epstein et al. 2014a; Park et al. 2014), xanthomatous cytoplasm as seen in foamy gland carcinoma (Nelson and Epstein 1996; Humphrey 2012), oncocytic cytoplasm (Pinto et al. 1994), and signet ring-like change (Humphrey 2012). None of these cytoplasmic changes is specific for malignancy.

The amount of cytoplasm can also be somewhat helpful in differential diagnosis of benignancy versus malignancy because prostatic carcinomas cells typically have a moderate amount of cytoplasm. In contrast, the benign entity most likely to be misdiagnosed as carcinoma-benign atrophy-has a scanty amount of cytoplasm. Amount of cytoplasm is not specific for a particular epithelial proliferation; however, as benign prostatic epithelial cells often have the same amount of cytoplasm as prostatic carcinoma cells and, moreover, the volume of prostatic carcinoma cytoplasm is low in atrophic pattern prostatic carcinoma.

Cellular characteristics that are not included in the diagnostic criteria checklist include cell size and shape and cytoplasmic borders. Carcinoma cellular borders can be distinct or not and the luminal border of gland-forming cells, although often flat, can be ruffled with bleb or snout formation.

\section{Histopathological Features Considered Specific for Carcinoma}

Histological features that have been considered specific for a diagnosis of prostatic carcinoma include extraprostatic spread of glands and, within the prostate, the findings of perineural invasion, collagenous micronodules, and glomeruloid intraglandular projections (Baisden et al. 1999).

The presence of prostatic glands outside the prostate is usually indicative of malignancy but it is important to know that ectopic benign prostatic glands have been found in many anatomic sites outside the prostate, including testis, epididymis, bladder, penile urethra, seminal vesicle, root of the penis, subvesical space, retrovesical space, pericolonic fat and submucosa, perirectal fat, urachal remnant, and spleen (Humphrey 2003b).

Perineural invasion is a hallmark of prostatic carcinoma. In whole prostate glands, perineural invasion can be found in the vast majority of cases with the range in the literature being 84\%-94\% (Byar and Mostofi 1972; Bostwick 1994). In needle core biopsy, about one-quarter of cases show perineural invasion, although, in a screening population with smaller lower-stage tumors, only $11 \%$ of cases had perineural invasion (Bismar et al. 2002). The diagnostic use of perineural invasion is diminished for a limited or minimal amount of carcinoma $(<1 \mathrm{~mm}$ in greatest dimension) in needle biopsy tissue, because the incidence decreases to as low as 
2\% in this setting (Epstein 1995; Thorson et al. 1998). The mere presence of prostatic glands immediately adjacent to nerve is not, however, definitively diagnostic of malignancy. Benign prostatic glands can abut or wrap around nerves (Ali and Epstein 2005). One should rely on cytologic features of the epithelial cells around a nerve to distinguish benign from malignant perineural epithelium.

Lymphovascular space invasion by prostatic epithelial cells can be also viewed as specific for a diagnosis of malignancy. This finding is, however, rare in needle core tissue. Lymphovascular invasion can be found in $5 \%-53 \%$ of radical prostatectomy cases. Intraprostatic lymphovascular invasion is associated with higher grade, volume, and stage, and is related to increased risk of biochemical failure, distant metastases, and overall survival after radical prostatectomy (Magi-Galluzzi et al. 2011; Fajkovic et al. 2016). True lymphovascular invasion should be distinguished from artifactual separation of malignant glands from stroma, impingement of cancer on vascular spaces, and displacement of benign glands into lymphovascular spaces (Kryvenko and Epstein 2012); this may require immunohistochemistry for endothelial cells, using CD31 or podoplanin (D2-40) antibodies.

Collagenous micronodules, also known as mucinous fibroplasia, are microscopic aggregates of hyalinized stroma that represent an unusual response to invasive adenocarcinoma of the prostate (McNeal et al. 1991; Bostwick et al. 1995; Baisden et al. 1999). They are often, but not always, associated with abundant mucin production. The micronodules are mainly composed of collagen and are paucicellular, with a few elongated fibroblastic nuclei seen. The collagen can form true nodules, vaguely lobulated masses, and streaks and strands of the collagenous tissue within mucinous pools. The micronodules can be located in stroma adjacent to adenocarcinomatous glands and also within glandular lumina. For diagnostic purposes, collagenous micronodules seem to be highly specific for carcinoma, but their overall diagnostic use is somewhat limited, because they are found in only $1 \%-2 \%$ of needle biopsies with carcinoma (Bostwick et al. 1995; Thorson et al. 1998;
Varma et al. 2002) and 13\%-22\% of carcinomas in whole glands in radical prostatectomy specimens (Bostwick et al. 1995; Kaleem et al. 1998). They are associated with Gleason pattern 3 or 4 adenocarcinoma (Kim et al. 2015).

Glomeruloid structures, or glomerulations, are renal glomerulus-like epithelial aggregates within acini of prostatic adenocarcinoma (Baisden et al. 1999). This pattern of intraluminal epithelial growth is thought to be specific for carcinoma (Pacelli et al. 1998). The diagnostic value of glomerulations is somewhat limited by their presence in just $3 \%-15 \%$ of needle biopsies with adenocarcinoma and $5 \%$ of radical prostatectomies with adenocarcinoma (Pacelli et al. 1998; Varma et al. 2002). Microscopically, glomeruloid bodies are characterized by rounded to ball-like tufts or buds into small to medium-size malignant glands. The glomeruloid bodies typically comprise only a minority of the carcinoma. They represent a high-grade Gleason pattern 4 (Epstein et al. 2016b).

\section{Diagnostic Immunohistochemistry}

Currently, the most valuable adjunctive technique for the diagnosis of adenocarcinoma of the prostate is immunohistochemistry with antibodies directed against basal cells (34ßE12 and $\mathrm{p} 63$ ) and $\alpha$-methylacyl-CoA racemase, or AMACR (also known as P504S and racemase) (Hameed and Humphrey 2005; Brimo and Epstein 2012; Epstein et al. 2014b). The best characterized basal cell immunostains use monoclonal antibody $34 \beta E 12$, which binds to high-molecular-weight cytokeratins expressed in the cytoplasm of basal cells and not luminal cells, and an antibody directed against p63, which is localized to basal cell nuclei. Cytokeratin 5/6 may also be used as a basal cell marker. A cocktail of p63 and $34 \beta \mathrm{E} 12$ antibodies appears to increase sensitivity of basal cell detection (Zhou et al. 2003a). It is important to be aware that some benign glands can have a discontinuous or absent basal cell layer. Indeed, one of the benign entities most often misdiagnosed as carcinoma - atrophy - can reveal scattered basal cell-negative glands in up to a quarter of cases (Hameed and Humphrey 2005). 
P.A. Humphrey

Also, on average, $50 \%$ (range: $10 \%$ to $90 \%$ ) of glands in atypical adenomatous hyperplasia (adenosis) do not stain for basal cells. Thus, diffuse absence of basal cells in the glands of concern by immunohistochemistry is most supportive, in the correct histological context, of a diagnosis of adenocarcinoma. Finally, there are exceedingly rare, molecularly distinctive, invasive adenocarcinomas that are p63 immunoreactive but negative for high molecular weight cytokeratins (Osunkoya et al. 2008a; Giannico et al. 2013; Tan et al. 2015).

AMACR immunostaining, for overexpression of this enzyme, has also assumed a prominent role as a confirmatory marker for prostatic carcinoma (Jiang et al. 2001; Rubin et al. 2002; Epstein et al. 2014b). An advantage of the AMACR immunostain is that it is a positive signal for neoplastic prostatic epithelial cells. This marker was discovered to be overexpressed in prostatic adenocarcinoma by cDNA library subtraction using high-throughput DNA microanalysis (Xu et al. 2000). In immunohistochemistry, this enzyme is selectively expressed in $80 \%-100 \%$ of prostatic carcinomas but it is not specific for carcinoma. Up to $20 \%$ of benign glands can also stain, but the staining is weaker and more focal than in carcinoma. Circumferential, granular cytoplasmic staining in prostatic carcinoma glands is characteristic. It is important to run an immunostain for basal cell marker(s) at the same time as the AMACR immunostain, because high-grade PIN and atypical adenomatous hyperplasia (adenosis) can also be AMACR-positive (but differ from carcinoma in having a least-fragmented basal cell layer). AMACR positivity can also be seen in atrophy (especially partial atrophy) and nephrogenic adenoma. Basal cell marker and AMACR immunostains can be run separately on different sections or slides on a single section or slide as a cocktail of p63/AMACR or as the so-called "triple stain" using three antibodies - 34 $\beta E 12 /$ p63/AMACR — and two chromogens, if only a few glands are available for evaluation (Jiang et al. 2005).

ERG expression, as detected by immunohistochemistry, is fairly specific for adenocarcinoma of the prostate (and vascular tumors) (Park et al.
2010; Miettinen et al. 2011) but its usage as a diagnostic marker is limited because of the relative lack of sensitivity with only $\sim 50 \%$ of prostatic adenocarcinomas being positive. It does not provide added value beyond basal cell markers and AMACR in diagnosis of minimal adenocarcinoma (Andrews and Humphrey 2014).

The differential diagnosis of high-grade adenocarcinoma of the prostate versus high-grade urothelial carcinoma can be aided by use of a targeted panel of antibodies in immunohistochemistry, with use of PSA, prostatic acid phosphatase (PAP), and NKX3.1 or prostein antibodies for prostatic adenocarcinoma and with usage of GATA3, p63, and 34ßE12 antibodies for urothelial carcinoma (Epstein et al. 2014b). PSA and GATA3 have been recommended as first-line markers (Epstein et al. 2014b).

The distinction of high-grade prostatic adenocarcinoma versus urinary bladder adenocarcinoma can be addressed with the prostatic markers PSA, PAP, and prostein. Villin, thrombomodulin, CDX2, and carcinoembryonic antigen (CEA) immunostains can be applied as urinary bladder adenocarcinoma markers (Epstein et al. 2014b).

Colonic adenocarcinoma can be distinguished from high-grade prostatic adenocarcinoma by use of PSA, PAP, prostein, and NKX3.1 immunostains (for prostatic differentiation) compared with expression of villin and CDX2 in colonic adenocarcinoma (Epstein et al. 2014b).

The diagnostic separation of small seminal vesicle glands and prostatic adenocarcinoma can usually be achieved by examination of $\mathrm{H} \& \mathrm{E}$-stained slides. When necessary, this can also be accomplished by PSA, PAP, and 34ßE12/p63/AMACR immunohistochemistry in which prostatic carcinoma glands will be positive for PSA, PAP, and AMACR and negative for basal markers with seminal vesicle glands showing the opposite immunophenotype (Harvey et al. 2010).

The tissue diagnosis of metastatic adenocarcinoma can be confirmed by positive PSA, PAP, prostein, and NKX3.1 immunostains. Each of these four prostatic markers displays $>94 \%$ sensitivity (Epstein et al. 2014b). PSA and PAP 
expression can be down-regulated with androgen deprivation therapy and NKX3.1 and prostein may be useful in this scenario. As far as specificity, PSA expression can be observed in salivary gland neoplasms and PAP immunoreactivity may be detected in salivary gland and neuroendocrine neoplasms. NKX3.1 and prostein are highly specific for metastatic adenocarcinoma of the prostate (Sheridan et al. 2007; Gurel et al. 2010). Markers that are not recommended for diagnosis of metastatic adenocarcinoma of the prostate in metastatic sites include prostate-specific membrane antigen, ERG, androgen receptor, and AMACR (Epstein et al. 2014b).

\section{Variants of Acinar Adenocarcinoma}

Variants of usual acinar adenocarcinoma include, according to the 2016 World Health Organization (WHO) scheme, the following: atrophic, pseudohyperplastic, microcystic, foamy, mucinous (colloid), signet ring-like cell, pleo-

Table 3. 2016 World Health Organization (WHO) classification of carcinomas and neuroendocrine tumors of the prostate

\begin{tabular}{l} 
Glandular neoplasms \\
Acinar adenocarcinoma \\
Atrophic \\
Pseudohyperplastic \\
Microcystic \\
Foamy gland \\
Mucinous (colloid) \\
Signet ring-like cell \\
Pleomorphic giant cell \\
Sarcomatoid \\
Intraductal carcinoma \\
Ductal adenocarcinoma \\
Urothelial carcinoma \\
Squamous neoplasms \\
Adenosquamous carcinoma \\
Squamous cell carcinoma \\
Basal cell carcinoma \\
Neuroendocrine tumors \\
Adenocarcinoma with neuroendocrine \\
differentiation \\
Well-differentiated neuroendocrine tumor \\
Small-cell neuroendocrine carcinoma \\
Large-cell neuroendocrine carcinoma \\
\hline
\end{tabular}

morphic giant cell, and sarcomatoid (Table 3) (Humphrey et al. 2016a). The first four variants (atrophic, pseudohyperplastic, microcystic, and foamy) are of significance because they are deceptively benign-appearing and may be difficult to diagnose. The last three variants (signet ring-like cell, pleomorphic giant cell, and sarcomatoid) harbor prognostic significance, with a worse prognosis compared with usual acinar adenocarcinoma.

Atrophic pattern adenocarcinoma may be seen in sporadic and postradiation or postandrogen deprivation therapy settings and is characterized by cytoplasmic volume loss, just like benign atrophy (Cinha and Epstein 1997; Egan et al. 1997; Reuter 1997; Kaleem et al. 1998). An infiltrative architecture, macronucleoli, nucleomegaly, and admixed nonatrophic usual acinar adenocarcinoma with a moderate amount of cytoplasm are useful findings in diagnostic recognition. Challenges in diagnosis include identification in some glands of nuclear atypia due to nuclear compression and diminished expression of AMACR, with $70 \%$ of cases being positive (Farinola and Epstein 2004). Complete loss of basal cells in all glands is seen in immunohistochemistry. Most atrophic pattern adenocarcinomas are Gleason pattern 3. The presence of atrophic features in adenocarcinoma is not likely of prognostic significance because adenocarcinomas with and without atrophic change do not differ in Gleason grade or pathologic stage (Kaleem et al. 1998).

Pseudohyperplastic adenocarcinoma can simulate the appearance of usual epithelial hyperplasia with papillary infoldings, luminal undulations and branching, and cystic dilatation (Humphrey et al. 1998; Wolf and Epstein 2000; Arista-Nasr et al. 2015). AMACR expression is detectable in $70 \%$ to $83 \%$ of cases (Zhou et al. 2003b) and no basal cells are found in the glands of concern by immunostaining. Pseudohyperplastic adenocarcinomas are Gleason pattern 3. The presence of pseudohyperplastic change does not impact pathological stage (Humphrey et al. 1998). Of note, HOXB13 G84E-related familial prostate cancers commonly show pseudohyperplastic features (Smith et al. 2014). 
P.A. Humphrey

Microcystic adenocarcinoma shows gland dilatation with intermediate-sized glands that are, on average, 10 times the size of usual small acinar adenocarcinoma glands (Yaskiv et al. 2010). The incidence in radical prostatectomy cases is $11 \%$. Microscopically, the expansion of the luminal spaces generates a rounded profile, and the luminal cell-lining layer is flat with or without atrophic changes. Intraluminal crystalloids and blue mucin are uniformly present. In immunohistochemistry, the dilated glands lack basal cells and almost all cases (96\%) express AMACR (Yaskiv et al. 2010). The Gleason pattern assignment is 3 .

Foamy gland adenocarcinoma is characterized by abundant foamy or xanthomatous-type cytoplasm with pyknotic nuclei being frequent (Nelson and Epstein 1996; Tran et al. 2001; Koca et al. 2014). Foamy glands are observed admixed with usual acinar adenocarcinoma in $17 \%$ of needle biopsy cases (Warrick and Humphrey 2013) and 13\%-23\% of radical prostatectomy cases (Hudson et al. 2012) and is only rarely found in pure form. The lack of nuclear atypia can create difficulty in establishment of a malignant diagnosis, especially in needle core tissue. Most foamy gland carcinomas are Gleason score 6 or 7, although Gleason score 8 to 10 carcinomas also exist. Foamy gland carcinoma has a similar prognosis as nonfoamy gland adenocarcinoma (Hudson et al. 2012).

Mucinous (colloid) adenocarcinoma is defined as prostatic adenocarcinoma with at least $25 \%$ of the tumor comprised of lakes of extracellular mucin (Ro et al. 1990; Saito and Iwaki 1999). It constitutes $\sim 0.3 \%$ of all prostatic adenocarcinomas. Microscopically mucinous adenocarcinoma shows tumor cells "floating" or embedded within prominent pools of mucin. Most cases are Gleason score 7 with a minority being Gleason score 6 or 8 (Osunkoya et al. 2008b). In the past, mucinous adenocarcinoma was thought to confer a worse prognosis than usual acinar adenocarcinoma but more recent reports suggest that mucinous adenocarcinoma is not more aggressive (Lane et al. 2006; Osunkoya et al. 2008b; Marcus et al. 2012).
Signet ring-like cell carcinoma is rare and is microscopically characterized by carcinoma cells with nuclear displacement and indentation by clear cytoplasmic vacuoles (Torbenson et al. 1998; Humphrey 2012). In contrast to signet-ring carcinomas at other sites, intracellular mucin may not be detectable by histochemical mucin stains of prostatic signet ring-like cell carcinoma. These signet ringlike cells can grow as sheets, cords, small clusters, and as single cells. Immunostains for PSA and PAP are positive in most cases. The assigned Gleason pattern is 5 . The outcome is poor with a mean survival of 28 months (Warner et al. 2010).

Pleomorphic giant cell carcinoma is extremely rare. Histological sections show giant pleomorphic nuclei with admixed high-grade usual acinar adenocarcinoma of Gleason score 9 (Lopez-Beltran et al. 2005; Parwani et al. 2006). These tumors are very aggressive.

Sarcomatoid carcinoma (also called carcinosarcoma) is a rare biphasic malignancy in the prostate with malignant epithelial and mesenchymal elements (Shannon et al. 1992; Dundore et al. 1995; Hansel and Epstein 2006). In about one-half of patients, the initial diagnosis was usual acinar adenocarcinoma, followed by hormonal and/or radiation therapy, with a subsequent diagnosis, after a mean of 7 years, of sarcomatoid carcinoma. Sarcomatoid carcinoma may be either homologous, in which the mesenchymal-like areas have the appearance of an undifferentiated sarcoma, or heterologous, in which the sarcoma shows differentiation along the lines of specific mesenchymal cells such as bone and cartilage. The carcinomatous portion is almost always glandular and acinar, whereas the sarcomatoid component often shows areas of undifferentiated spindled and pleomorphic cells arranged in sheets, pinwheels, or fascicles resembling pleomorphic undifferentiated sarcoma. Osteosarcoma and chondrosarcoma are by far the most frequently identified heterologous elements. The prognosis for these patients is poor, although recent data suggest that localized disease can be effectively treated with surgery and/or radiation therapy (Markowski et al. 2015). 


\section{VARIANTS/TYPES OF NONACINAR CARCINOMA}

These prostatic carcinoma variants/types include, according to the 2016 WHO classification (Humphrey et al. 2016a), ductal adenocarcinoma, urothelial carcinoma, squamous neoplasms, basal cell carcinoma, and neuroendocrine tumors (Table 3).

Ductal adenocarcinoma is a subtype of adenocarcinoma of the prostate with typically large glands lined by tall pseudostratified columar cells (Fig. 5) (Egevad et al. 2016b; Seipel et al. 2016). Pure ductal and mixed ductalacinar carcinomas comprise $\sim 1 \%$ and $5 \%$ of all prostatic carcinomas, respectively (Dube et al. 1973). Obstruction and hematuria are common clinical manifestations, unlike usual acinar adenocarcinoma. Macroscopically, at urethroscopy, there may be an exophytic, villous/polypoid growth protruding into the urethra at or near the verumontanum. Microscopically, papillary and cribriform architectures are often found, although solid and single separate PIN-like patterns are less common (Hameed and Humphrey 2006; Tavora and Epstein 2008). A prominent in situ neoplastic component is often seen. The immunophenotype and gene expression profile are similar to acinar adenocarcinoma (Sanati et al. 2009; Seipel et al. 2016). The proliferation index is higher in ductal adenocarcinoma than acinar adenocarcinoma but overlap precludes its

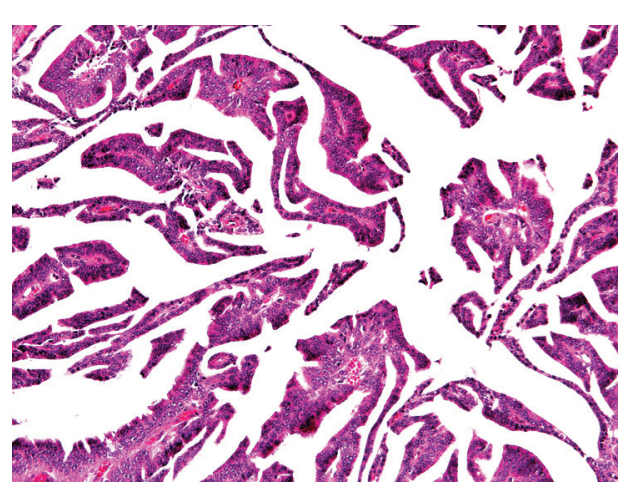

Figure 5. Ductal type of adenocarcinoma of the prostate with papillary growth. This is a high-grade (Gleason score 8) prostate cancer. use. No marker currently will distinguish acinar and ductal adenocarcinomas of the prostate. The spread of ductal adenocarcinoma is the same as for acinar adenocarcinoma, although ductal adenocarcinoma has a propensity to spread to testis, penis, and lung. In most studies, the outcome for men with pure or predominantly ductal adenocarcinoma is worse than for average acinar adenocarcinoma, likely the result of higher stage and grade. The Gleason grade of ductal adenocarcinoma is usually 4, but uncommonly patterns 3 (PIN-like pattern) or 5 (solid and comedo patterns) can be seen.

Urothelial carcinoma in the prostate usually represents secondary involvement but can arise as a primary in the large, central, primary ducts of the prostate that are normally lined by urothelium (Greene et al. 1973; Cheville et al. 1998; Shen et al. 2006; Grignon 2016). Microscopically, prostatic urothelial carcinoma has a striking propensity for growth within prostatic ducts and acini with solid cylinders, with or without comedo necrosis, being common. Pagetoid and undermining spread of the neoplastic urothelial cells within benign prostatic epithelium may be visualized. Stromal invasion is typified by irregular nests and cords of pleomorphic tumor cells, which often have a squamoid, eosinophilic cytoplasm. As noted above, urothelial markers that can be useful in the distinction versus prostatic adenocarcinoma include thrombomodulin, GATA3, p63, and high molecular weight cytokeratins. Urothelial carcinomas are negative for PSA, PAP, NKX3.1, and prostein in immunohistochemistry. Outcome is dependent on pathologic stage (Shen et al. 2006; Grignon 2016).

Squamous and adenosquamous carcinomas primary in the prostate are exceedingly rare (Parwani et al. 2004; Marcus et al. 2012). Many are diagnosed after radiation or hormonal therapy. One should exclude secondary involvement of the prostate by bladder squamous carcinoma or urothelial carcinoma with squamous differentiation. Survival is, on average, 1 year.

Basal cell carcinoma is a malignant neoplasm of prostatic basal cells. They are extraordinarily rare tumors that can resemble, to a certain degree, adenoid cystic carcinomas of 
P.A. Humphrey

the salivary glands (Yang et al. 1998; Iczkowski et al. 2003; Ali and Epstein 2007; Simper et al. 2015). Microscopically, growth arrangements include adenoid cystic/cribriform patterns and small solid nests with peripheral palisading. Other patterns include a basal cell hyperplasia-like arrangement, small tubules with a hyaline rim, and large solid nests with or without necrosis. Bcl-2 expression and a higher Ki-67 proliferation index favor basal cell carcinoma more than basal cell hyperplasia (Yang et al. 1998). A subset of cases with the adenoid cystic-like pattern show $M Y B$ rearrangement (Bishop et al. 2015). Extraprostatic extension has been reported in a minority of cases and metastasis has been detected in $\sim 15 \%$ of cases. The solid nested pattern is associated with more aggressive behavior.

Neuroendocrine carcinomas in the prostate include adenocarcinoma with neuroendocrine differentiation, small-cell neuroendocrine carcinoma, and large-cell neuroendocrine carcinoma (Epstein et al. 2014a, 2016a). Usual acinar adenocarcinoma expresses neuroendocrine markers such as chromogranin, synaptophysin, and CD56 in $10 \%$ to $100 \%$ of cases. Immunostains for these markers are not recommended for routine use in diagnosis of typical adenocarcinoma. The significance of the expression of these markers is uncertain (Epstein et al. 2016a). Acinar adenocarcinoma may also show Paneth-like cells with neuroendocrine cytoplasmic granules. Small-cell carcinoma primary in the prostate is a rare, extremely aggressive malignancy that often presents with disseminated disease (Têtu et al. 1987; Wang and Epstein 2008; Epstein et al. 2014a, 2016a; Nadal et al. 2014). In about one-half of cases, the carcinoma is pure small-cell carcinoma and, in the other half, there is an admixture with prostatic acinar adenocarcinoma. An intriguing and important aspect of prostatic small-cell carcinoma diagnosis is that in one-third of patients there is an initial diagnosis of adenocarcinoma followed by therapy, usually hormonal, in turn followed (at a median of 18-49 months, range: 7 months to 8 years) by a subsequent diagnosis of small-cell carcinoma. Microscopically, prostatic small-cell carcinoma grows as sheets, with ribbons, nests, and occasional rosette-like structures noted. The admixed adenocarcinoma is variable in grade and extent. Proof of prostatic origin of metastatic small-cell carcinoma can be accomplished in $46 \%$ to $86 \%$ of cases by detection of TMPRSS2-ERG gene fusion by FISH (Scheble et al. 2010; Guo et al. 2011; Schelling et al. 2013). Neuroendocrine markers (synaptophysin, chromogranin, and CD56) are detected in $\sim 90 \%$ of cases. The prostatic markers PSA, PAP, PSMA, and prostein, in contrast, are identified by immunostaining in only a small minority of cases of prostatic small-cell carcinoma (Yao et al. 2006; Epstein et al. 2014b). The median average survival for patients with smallcell carcinoma of the prostate is 1 to 2 years. Large-cell neuroendocrine carcinoma of the prostate is extremely rare (Evans et al. 2006). Sections show large nests with peripheral palisading and sometimes geographic necrosis. The mean survival is 7 months.

\section{TREATMENT EFFECTS}

Grossly, the prostates of men treated with androgen deprivation therapy are small and atrophic. Microscopically, androgen deprivation therapy effects on prostatic adenocarcinoma include a decrease in number of malignant glands with loss of luminal glandular spaces (luminal collapse), increased stroma, nuclear pyknosis, and cytoplasmic vacuolization (Armas et al. 1994; Srigley et al. 2012). These treated carcinoma cells can resemble lymphocytes or histiocytes. Histologic grading of prostatic carcinoma after hormonal therapy is not recommended because the architectural changes of luminal collapse simulate high-grade carcinoma (Humphrey et al. 2016a). Immunostains for PSA, low molecular weight cytokeratins, basal cells, and AMACR may be of use in identification of histologically inconspicuous carcinoma cells with treatment effect. AMACR is, however, down-regulated by androgen deprivation therapy in some cases, with $45 \%$ to $71 \%$ of cases being positive (Suzue et al. 2005; Sung et al. 2007).

Hormonal treatment with $5 \alpha$ reductase inhibitors such as finasteride and dustasteride has a minimal-to-absent effect on prostatic carcino- 
ma histomorphology and so Gleason grades may still be assigned after this type of treatment (Srigley et al. 2012). The finasteride-induced selective suppression of low-grade prostate cancer in the Prostate Cancer Prevention Trial may be due, in part, to the differential effect of finasteride on apoptosis and androgen receptor expression in low-grade (Gleason pattern 3) compared with higher-grade (Gleason pattern 4) tumors (Kim et al. 2016).

Radiation therapy-induced histological changes in carcinoma are a decrease in number of tumor glands, generation of poorly formed glands and single cells, cytoplasmic vacuolization, nuclear pyknosis, and stromal fibrosis (Cheng et al. 1999). Gleason grading should be attempted when there is no obvious radiotherapy effect but should not be performed when there is marked radiotherapy effect. Such severe radiation therapy histomorphologic effect on carcinoma cells should be reported because these patients have the same prognosis as patients without carcinoma (Crook et al. 2009). Immunohistochemistry for basal cells and AMACR can be of value in the differential diagnostic consideration of benign prostatic epithelial cells with radiotherapy-induced atypia, which can be striking, and in detection of carcinoma cells with marked radiotherapy effect.

Neoadjuvant chemotherapy with docetaxel, docetaxel with mitoxantrone, or abiraterone and enzalutamide induces inconspicuous collapsed glands, small inconspicous individual tumor cells, cytoplasmic vacuolization, and intraductal and cribriform growth patterns (Magi-Galluzzi et al. 2007; O’Brien et al. 2010; Murphy et al. 2016). A three-group system has been proposed to classify these histological alterations (Efstathoiu et al. 2010). Intraductal carcinoma and a cribriform growth pattern in radical prostatectomy tissue sections (group C tumors) are associated with adverse clinical outcome after neoadjuvant chemotherapy (Efstathoiu et al. 2010; O'Brien et al. 2010).

Cryosurgery can cause necrosis and nonspecific halinization, fibrosis, calcification, and hemosiderin deposition (Borkowski et al. 1996). High-intensity ultrasound treatment may produce fibrosis, inflammation, and necro- sis (Biermann et al. 2010; Ryan et al. 2012). No significant therapy-specific changes in the residual carcinoma are identified. Gleason grading may be performed for residual carcinoma detected after these treatments.

\section{GRADING OF PROSTATE CANCER}

The Gleason grading system is currently the most widely used histologic grading scheme for prostatic adenocarcinoma in the United States and worldwide (Gleason 1966, 1992; Gleason et al. 1974, 1977; Humphrey et al. 2016a,b). The Gleason grading method is based entirely on architectural arrangements of prostatic carcinoma (Fig. 1). The grading diagram depicting Gleason patterns has undergone modifications from the original diagram. This most current diagram is based on modifications according to a 2014 consensus meeting of the ISUP published in 2016 (Epstein et al. 2016b) and was endorsed by the World Health Organization (Fig.1) (Humphrey et al. 2016a,b).

In the Gleason system, the histologic patterns are categorized into five basic grade patterns at relatively low magnification (using a $4 \times$ or $10 \times$ objective) by the extent of glandular differentiation and the pattern of growth of the tumor in the prostatic stroma. These five basic grade patterns are used to generate a histologic score, which can range from 2 to 10 , by adding the primary grade patterns and the secondary grade pattern. The primary pattern is the one that is predominant in area on simple visual inspection. The secondary pattern is the second most common pattern. If only one grade is in the tissue sample, then that grade is multiplied by two to give the score. If, however, high-grade (pattern 4 or 5) carcinoma is present, and a low-grade pattern occupies $<5 \%$ of the tumor, then the low-grade component should not be included in the score. For example, if a tumor is $96 \%$ pattern 4 and $4 \%$ pattern 3 , then the score should be $4+4=8$. In needle biopsy samples, a high-grade pattern of any amount should always be incorporated into the score. So, in needle biopsy of $96 \%$ pattern 3 and $4 \%$ pattern 4 , the score is $3+4=7$. A Gleason grade ( primary + secondary $=$ score $)$ 
P.A. Humphrey

should be provided for all primary adenocarcinomas diagnosed in prostatic tissue, even minimal adenocarcinoma in needle biopsy tissue. The only setting in which a prostatic adenocarcinoma should not be assigned a Gleason grade is when there is a hormonal or a radiation therapy effect. Note that Gleason grading is applicable only to adenocarcinomas within the prostate gland.

The Gleason grading system allows for two separate grade patterns in an individual tissue sample, but the histomorphological appearance of prostatic carcinoma is more heterogeneous than this. Indeed, in one study, an average of 2.7 Gleason grade patterns (range 1-5) was found in carcinomas in whole prostate glands (Aihara et al. 1994). The number of grades assigned depends on tumor sample size and size of the tumor in the whole gland. In needle biopsy tissue, $4 \%$ of cases have more than two grades, whereas tumors $>1-2 \mathrm{~cm}^{3}$ in size in radical prostatectomy tissue sections tend to have more than two grades (Aihara et al. 1994; Ruijter et al. 1996).

Tertiary grades are handled differently depending on the tissue sample. For needle biopsies with patterns 3,4 , and 5 , the score is assigned using the predominant pattern and the highest grade (Epstein et al. 2005; Epstein 2010). So, for patterns $4+3+5$, in order of pattern amount, the Gleason score is $4+5=$ 9. For radical prostatectomy specimens, the presence of a third pattern that is $<5 \%$ of the tumor and that is higher in grade than the primary and secondary grades should be noted in the report rather than incorporated into the score. So $3+4+5$, in order of pattern amount in radical prostatectomy should be diagnosed as $3+4=$ score of 7 with a tertiary pattern 5. This is so because the outcome for these patients is intermediate between score of 7 and score of 8 . It is clear that a high-grade Gleason pattern 4 or 5 that is a tertiary component occupying $<5 \%$ of the tumor in the whole gland influences pathological stage and progression rates (Pan et al. 2000; Mosse et al. 2004; Hattab et al. 2006).

Comparison of needle biopsy Gleason grade with grade in the matched whole glands reveals reasonable agreement, but undergrading is common. Intraobserver and interobserver variability in Gleason grade assignment does exist (Allsbrook et al. 2001a), but a substantial degree of interobserver agreement can be achieved (Allsbrook et al. 2001b). For needle biopsy cases, there are several sources of grading error, including difficulty in appreciation of an infiltrative growth pattern, tissue sampling error (related to the small amount of tissue supplied by needle biopsy and grade heterogeneity), tissue distortion, pathologist experience, and observer variability.

Percentage of prostate cancer that is highgrade Gleason pattern 4 or 5 is an important prognostic indicator ( $\mathrm{McNeal}$ et al. 1990; Stamey et al. 1999; Egevad et al. 2002; Cheng et al. 2007). The 2016 WHO Classification of Tumors of the Urinary System and Male Genital Organs recommends reporting percentage pattern 4 for Gleason score 7 adenocarcinomas (Humphrey et al. 2016a). Risk stratification based on percentage pattern 4 has been shown for Gleason score 7 adenocarcinoma in needle biopsy (Cole et al. 2016) and radical prostatectomy (Choy et al. 2016; Sauter et al. 2016) tissues. Knowledge of the percentage pattern 4 in Gleason score 7 adenocarcinoma in needle biopsy tissue may be useful in selection of patients for active surveillance (Morash et al. 2015; Chen et al. 2016). In particular, select patients with clinically localized Gleason grade $3+4=$ score of 7 adenocarcinoma with $\leq 10 \%$ pattern 4 may be candidates for active surveillance (Morash et al. 2015). Assessment of percentage Gleason pattern 4 is relatively reproducible (Sadimin et al. 2016), although it may be a challenge to visually estimate parentage pattern 4 when patterns 3 and 4 are intermingled, which is a common occurrence (Egevad et al. 2016a).

Grade groups should be reported along with the 2014 WHO/ISUP-modified Gleason score (Epstein et al. 2016b; Humphrey et al. 2016a). These grade groups are defined in Table 2 (Pierorazio et al. 2013). A rationale for their use is that Gleason score 6 of 10, which suggests intermediate grade, is now more appropriately categorized as the lowest grade group 1 of 5 , 
thereby informing physicians and patients of the relatively indolent nature of this large group of prostate cancers (Epstein et al. 2016b). Additionally, the grading is simplified into five categories rather than 12 , and the grade groups appear to provide better stratification of risk compared with standard Gleason scoring, using Gleason score categories of 6 versus 7 versus 8-10 (Spratt et al. 2016a,b). Prognostic use of the grade groups, which have been termed ISUP grade in some publications, has been validated in a number of studies (Delahunt et al. 2015; Samaratunga et al. 2015; Berney et al. 2016; Epstein et al. 2016d; Spratt et al. 2016a,b). Of interest, there are genomic correlates to and molecular support for the grade group system (Rubin et al. 2016).

\section{HISTOPATHOLOGIC APPEARANCE OF PROSTATIC ADENOCARCINOMA THAT IS LOCALLY ADVANCED OR METASTATIC}

The histopathologic appearance of prostatic adenocarcinoma that has spread outside the prostate gland often resembles one of the patterns in the primary tumor and is usually highgrade Gleason pattern 4 or 5 . Gleason grading is not, however, applied to prostatic adenocarcinoma that is outside the prostate. Diagnostic difficulty can arise in patients with metastatic prostate cancer treated with androgen deprivation agents when the metastatic adenocarcinoma cells show hormonal treatment effect such that the malignant cells appear benign and morphologically simulate histiocytes.

When a man presents with metastatic adenocarcinoma of unknown primary origin, the histomorphological appearance of a carcinoma with uniform nuclei and prominent nucleoli may suggest a prostatic primary but immunohistochemical stains for PSA, PAP, and NKX3.1 should always be performed to support a diagnosis of metastastic adenocarcinoma of the prostate.

\section{CONCLUDING REMARKS}

Histopathologic assessment of H\&E-stained tissue sections with use of immunohistochem- istry in select cases is currently the standard approach in diagnosis and characterization of prostate cancer. In the future, additional molecular markers beyond the proteins currently targeted in immunohistochemistry and including RNA expression profiles and DNA abnormalities may be of use in tissue diagnosis of prostate cancer and in risk stratification of patients with prostate cancer.

\section{REFERENCES}

Adlakha H, Bostwick DG. 1994. Paneth cell-like change in prostatic adenocarcinoma represents neuroendocrine differentiation. Report of 30 cases. Hum Pathol 25: 135-139.

Aihara M, Wheeler TM, Ohori M, Scardino PT. 1994. Heterogeneity of prostate cancer in radical prostatectomy specimens. Urology 43: 60-66.

Ali TZ, Epstein JI. 2005. Perineural involvement by benign prostatic glands on needle biopsy. Am J Surg Pathol 29: 1159-1163.

Ali TZ, Epstein JI. 2007. Basal cell carcinoma of the prostate: A clinicopathologic study of 29 cases. Am J Surg Pathol 31: 697-705.

Allsbrook WCJr, Mangold KA, Johnson MH, Lane RB, Lane CG, Epstein JI. 2001a. Interobserver reproducibility of Gleason grading of prostatic carcinoma. General pathologists. Hum Pathol 32: 81-88.

Allsbrook WCJr, Mangold KA, Johnson MH, Lane RB, Lane CG, Amin MB, Bostwick DG, Humphrey PA, Jones EC, Reuter VE, et al. 2001b. Interobserver reproducibility of Gleason grading of prostatic carcinoma. Urologic pathologists. Hum Pathol 32: 74-80.

Andrews C, Humphrey PA. 2014. Utility of ERG versus AMACR expression in diagnosis of minimal adenocarcinoma of the prostate in needle biopsy tissue. Am J Surg Pathol 38: 1007-1012.

Arista-Nasr J, Martinez-Benitez B, Aguilar-Ayala EL, Aleman-Sanchez CN, Bornstein-Quevedo L, Albores-Saavedra J. 2015. Pseudohyperplastic prostate carcinoma: Histologic patterns and differential diagnosis. Ann Diagn Pathol 19: 253-260.

Armas OA, Aprikian AG, Melamed J, Cordon-Cardo C, Cohen DW, Erlandson R, Fair WR, Reuter VE. 1994. Clinical and pathological effects of neoadjuvant total androgen ablation therapy on clinically localized prostatic adenocarcinoma. Am J Surg Pathol 18: 979-991.

Baisden BL, Kahane H, Epstein JI. 1999. Perineural invasion, mucinous fibroplasia, and glomerulations. Diagnostic features of limited cancer on prostate needle biopsy. Am J Surg Pathol 23: 918-924.

Berney DM, Beltran L, Fisher G, North BV, Greenberg D, Moller H, Soosay G, Scardino P, Cuzik J. 2016. Validation of a contemporary prostate cancer grading system using prostate cancer death as outcome. Br J Cancer 114: 10781083.

Biermann K, Montironi R, Lopez-Beltran A, Zhang S, Cheng L. 2010. Histopathological findings after treat- 
P.A. Humphrey

ment of prostate cancer using high-intensity focused ultrasound (HIFU). Prostate 70: 1196-1200.

Bishop JA, Yonescu R, Epstein JI, Westra WH. 2015. A subset of prostatic basal cell carcinomas harbor the MYB rearrangement of adenoid cystic carcinoma. Hum Pathol 46: $1204-1208$.

Bismar TA, Lewis JSJr, Vollmer RT, Humphrey PA. 2002. Multiple measures of carcinoma extent versus perineural invasion in prostate biopsy tissue in prediction of pathologic stage in a screening population. Am J Surg Pathol 27: $432-440$.

Borkowski P, Robinson MJ, Poppiti RJ Jr, Nash SC. 1996. Histologic findings in postcryosurgical biopsies. Mod Pathol 9: 807-811.

Bostwick DG. 1994. Gleason grading of prostatic needle biopsies. Correlation with grade in 316 matched prostatectomies. Am J Surg Pathol 18: 796-803.

Bostwick DG, Wollan P, Adlakah K. 1995. Collagenous micronodules in prostate cancer. A specific but infrequent diagnostic finding. Arch Pathol Lab Med 119: 444-447.

Brimo F, Epstein JI. 2012. Immunohistochemical pitfalls in prostate pathology. Hum Pathol 43: 313-324.

Byar DP, Mostofi FK. 1972. Carcinoma of the prostate: Prognostic evaluation of certain pathologic features in 208 radical prostatectomies. Examined by the step-section technique. Cancer 30: 5-13.

Chen RC, Rumble RB, Loblaw DA, Finelli A, Ehdaie B, Cooperberg MR, Morgan SC, Tyldesley JJ, Tan W, Justman SJ, et al. 2016. Active surveillance for the management of localized prostate cancer (Cancer Care Ontario Guideline): American Society of Clinical Oncology Clinical Practice Guideline Endorsement. J Clin Oncol 34: 2182-2190.

Cheng L, Cheville JC, Bostwick DG. 1999. Diagnosis of prostate cancer in needle biopsies after radiation therapy. Am J Surg Pathol 23: 1173-1183.

Cheng L, Davidson DD, Lin H, Koch MO. 2007. Percentage of Gleason pattern 4 and 5 predicts survival after radical prostatectomy. Cancer 110: 1967-1972.

Cheville JC, Dundore PA, Bostwick DG, Lieber MM, Batts KP, Sebo TJ, Farrow GM. 1998. Transitional cell carcinoma of the prostate. Clinicopathologic study of 50 cases. Cancer 82: 703-707.

Cheville J, Algaba F, Epstein JI, Lopez-Beltran A. 2016. Mesenchymal tumours. In WHO classification of tumours of the urinary system and male genital organs (ed. Moch $\mathrm{H}$, et al.), pp. 175-177. IARC, Lyon, France.

Choy B, Pearce SM, Anderson BB, Shalhav AL, Zagaja G, Eggener SE, Paner GP. 2016. Prognostic significance of percentage and architectural types of contemporary Gleason pattern 4 prostate cancer in radical prostatectomy. Am J Surg Pathol 40: 1400-1406.

Christian JD, Lamm TC, Morrow JF, Bostwick DG. 2005. Corpora amylacea in adenocarcinoma of the prostate: Incidence and histology within needle core biopsies. Mod Pathol 18: 36-39.

Cinha SJ, Epstein JI. 1997. Adenocarcinoma of the prostate with atrophic features. Am J Surg Pathol 21: 287-295.

Cole AI, Morgan TM, Spratt DE, Palapattu GS, He C, Tomlins SA, Weizer AZ, Feng FY, Wu A, Siddiqui J, et al. 2016. Prognostic value of percent Gleason grade 4 at prostate biopsy on predicting prostatectomy pathology and recurrence. J Urol 196: 405-411.

Crook JM, Malone S, Perry G, Eapen L, Owen J, Robertson S, Ludgate C, Fung S, Lockwood G. 2009. Twenty-four month postradiation biopsies are strongly predictive of 7-year disease-free survival: Results from a Canadian randomized trial. Cancer 115: 673-679.

Delahunt B, Egevad L, Srigley JR, Steigler A, Murray JD, Atkinson C, Matthews J, Duchesne G, Spry NA, Christie D, et al. 2015. Validation of International Society of Urological Pathology (ISUP) grading for prostatic adenocarcinoma in thin core biopsies using TROG 03.04 "RADAR" trial clinical data. Pathology 47: 520-525.

Divatia MK, Ro JY. 2016. Intraductal carcinoma of the prostate gland: Recent advances. Yonsei Med J 57: 1054-1062.

Dube VE, Farrow GM, Greene LF. 1973. Prostatic adenocarcinoma of ductal origin. Cancer 32: 402-409.

Dundore PA, Cheville CJ, Nascimento AG, Farrow GM, Bostwick DG. 1995. Carcinosarcoma of the prostate. Report of 21 cases. Cancer 76: 1035-1042.

Efstathoiu E, Abrahams NA, Tibbs RF, Wang X, Pettaway CA, Pisters LL, Mathew PF, Do KA, Logothetis CJ, Troncoso P. 2010. Morphologic characterization of preoperatively treated prostate cancer: Toward a post-therapy histologic classification. Eur Urol 57: 1030-1038.

Egan JM, Lopez-Beltran A, Bostwick DG. 1997. Prostatic adenocarcinoma with atrophic features: Malignancy mimicking a benign process. Am J Surg Pathol 21: 931935.

Egevad L, Granfors T, Karlberg L, Bergh A, Stattin P. 2002. Percent Gleason grade $4 / 5$ as prognostic factor in prostate cancer diagnosed at transurethral resection. J Urol 168: 509-513.

Egevad L, Delahunt B, Samaratunga H, Srigely JR. 2016a. Utility of reporting the percentage of high-grade cancer. Eur Urol 69: 599-600.

Egevad L, Epstein JI, Hameed O, Humphrey PA, Samaratunga H. 2016b. Ductal adenocarcinoma. In WHO classification of tumours of the urinary system and male genital organs (ed. Moch H, et al.), pp. 166-167. IARC, Lyon, France.

Epstein JI. 1995. Diagnostic criteria of limited adenocarcinoma of the prostate on needle biopsy. Hum Pathol 26: 223-229.

Epstein JI. 2010. An update of the Gleason grading system. J Urol 183: 443-440.

Epstein JI, Allsbrook WCJr, Amin MB, Egevad LL; ISUP Grading Committee. 2005. The 2005 International Society of Urological Pathology (ISUP) Consensus Conference on Gleason Grading of Prostatic Carcinoma. Am J Surg Pathol 29: 1228-1242.

Epstein JI, Amin MB, Beltran H, Lotan TL, Mosquera JM, Reuter VE, Robinson BD, Troncoso P, Rubin MA. 2014a. Proposed morphologic classification of prostate cancer with neuroendocrine differentation. Am J Surg Pathol 38: 756-767.

Epstein JI, Egevad L, Humphrey PA, Montironi R; Members of the ISUP Immunohistochemistry in Diagnostic Urologic Pathology Group. 2014b. Best practices recommendations in the application of immunohistochemistry in the prostate: Report from the International Society of 
Urologic Pathology Consensus Conference. Am J Surg Pathol 38: e6-e19.

Epstein JI, Amin MB, Evans AJ, Huang J, Rubin MA. 2016a. Neuroendocrine tumours. In WHO classification of tumours of the urinary system and male genital organs (ed. Moch H, et al.), pp. 172-174. IARC, Lyon, France.

Epstein JI, Egevad L, Amin MB, Delahunt B, Srigley JR, Humphrey PA. 2016b. The 2014 International Society of Urological Pathology (ISUP) Consensus Conference on Gleason Grading of Prostatic Carcinoma: Definition of grading patterns and proposal for a new grading system. Am J Surg Pathol 40: 244-252.

Epstein JI, Oxley J, Ro JY, Van der Kwast T, Zhou M. 2016c. Intraductal carcinoma. In WHO classification of tumours of the urinary system and male genital organs (ed. Moch $\mathrm{H}$, et al.), pp. 164-165. IARC, Lyon, France.

Epstein JI, Zelefsky MJ, Sjoberg DD, Nelson JB, Egevad L, Magi-Galluzzi C, Vickers AJ, Parwani AV, Reuter VE, Fine SW, et al. 2016d. A contemporary prostate cancer grading system: A validated alternative to the Gleason score. Eur Urol 69: 428-435.

Evans AJ, Humphrey PA, Belani J, van der Kwast TH, Srigley JR. 2006. Large cell neuroendocrine carcinoma of the prostate: A clinicopathologic summary of 7 cases of a rare manifestation of advanced prostate cancer. $A m J$ Surg Pathol 30: 684-693.

Fajkovic H, Mathieu R, Lucca I, Hiess M, Hubner N, Al Hussein Al Awamlh B, Lee R, Briganti A, Karakiewicz P, Lotan Y, et al. 2016. Validation of lymphovascular invasion is an indepenedent prognostic factor for biochemical recurrence after radical prostatectomy. Urol Oncol 34: 233.e1-e6.

Farinola MA, Epstein JI. 2004. Utility of immunohistochemistry for $\alpha$-methylacyl-CoA reacemase in distinguishing atrophic prostate cancer from benign atrophy. Hum Pathol 35: 1272-1278.

Ferry JA. 2016. Hematolymphoid tumours. In WHO classification of tumours of the urinary system and male genital organs (ed. Moch H, et al.), p. 178. IARC, Lyon, France.

Giannico GA, Ross HM, Lotan T, Epstein JI. 2013. Aberrant expression of $\mathrm{p} 63$ in adenocarcinoma of the prostate: A radical prostatectomy study. Am J Surg Pathol 37: 14011406.

Giannulis I, Montironi R, Galluzzi CM, de Nictolis M, Diamanti L. 1993. Frequency and location of mitoses in prostatic intraepithelial neoplasia (PIN). Anticancer Res 13: 2447-2451.

Gleason DF. 1966. Classification of prostate carcinoma. Cancer Chemother Rep 50: 125-128.

Gleason DF. 1992. Histologic grading of prostate cancer: A perspective. Hum Pathol 23: 273-279.

Gleason DF, Mellinger GT; Veterans Administration Cooperative Urological Research Group. 1974. Prediction of prognosis for prostatic adenocarcinoma by combined histological grading and clinical staging. J Urol 111: 58-64.

Gleason DF; Veterans Adminstration Cooperative Urological Research Group. 1977. Histologica grading and clinical staging of prostatic carcinoma. In Urologic pathology: The prostate (ed. Tannenbaum M), pp. 171-197. Lea \& Febinger, Philadelphia.
Gottipati S, Warncke J, Vollmer R, Humphrey PA. 2012 Usual and unusual histologic patterns of high Gleason score 8 to 10 adenocarcinoma of the prostate in needle biopsy tissue. Am J Surg Pathol 36: 900-907.

Greene LF, Mulchay JJ, Warren MM, Dockerty MB. 1973. Primary transitional cell carcinoma of the prostate. J Urol 110: $235-237$.

Grignon DJ. 2016. Urothelial carcinoma. In WHO classification of tumours of the urinary system and male genital organs (ed. Moch H, et al.), pp. 168-169. IARC, Lyon, France.

Guo CC, Epstein JI. 2006. Intraductal carcinoma of the prostate on needle biopsy: Histologic features and clinical significance. Mod Pathol 19: 1528-1535.

Guo CC, Dancer JY, Wang W, Aparicio A, Navone NM, Troncoso P, Czerniak BA. 2011. TMPRSS2-ERG gene fusion in small cell carcinoma of the prostate. Hum Pathol 42: 11-17.

Gurel B, Ali TZ, Montgomery EA, Begum S, Hicks J, Goggins M, Eberhart CG, Clark DP, Bieberich CJ, Epstein JI, et al. 2010. NKX3.1 as a marker of prostatic origin in metastatic tumors. Am J Surg Pathol 34: 1097-1105.

Haffner MC, Weier C, Xu MM, Vaghasia A, Gurel B, Gumuskaya B, Esposi DM, Fedor H, Tan HL, Kulac I, et al. 2016. Molecular evidence that invasive adenocarcinoma can mimic prostatic intraepithelial neoplasia (PIN) and intraductal carcinoma through retrograde glandular colonization. J Pathol 238: 31-41.

Hameed O, Humphrey PA. 2005. Immunohistochemistry in diagnostic surgical pathology of the prostate. Semin Diagn Pathol 22: 84-104.

Hameed O, Humphrey PA. 2006. Stratified epithelium in prostatic adenocarcinoma: A mimic of high-grade prostatic intraepithelial neoplasia. Mod Pathol 19: 899-906.

Hansel DE, Epstein JI. 2006. Sarcomatoid carcinoma of the prostate: A study of 42 cases. Am J Surg Pathol 30: 13161321.

Harvey AM, Grice B, Hamilton C, Truong LD, Ro JY, Ayala A, Zhai QJ. 2010. Diagnostic utility of P504S/p63 cocktail, prostate-specific antigen, and prostatic acid phosphatase in verifying prostatic carcinoma involvement in seminal vesicles: A study of 57 cases of radical prostatectomy specimens of pathologic stage pT3b. Arch Pathol Lab Med 134: 983-988.

Hattab EM, Koch MO, Eble JN, Lin H, Cheng L. 2006. Tertiary Gleason pattern 5 is a powerful predictor of biochemical relapse in patients with Gleason score 7 prostatic adenocarcinoma. J Urol 175: 1695-1699.

Henneberry JM, Kahane H, Humphrey PA, Keetch DW, Epstein JI. 1997. The significance of intraluminal crystalloids in benign prostatic glands on needle biopsy. Am J Surg Pathol 21: 725-728.

Hudson J, Cao D, Vollmer R, Kibel AS, Grewal S, Humphrey PA. 2012. Foamy gland carcinoma of the prostate: Incidence, Gleason grade, and early clinical outcome. Hum Pathol 43: 974-979.

Humphrey PA. 2003a. Unusual prostatic neoplasms. In Prostate pathology (ed. Humphrey PA), pp. 430-455. ASCP, Chicago.

Humphrey PA. 2003b. Prostatic tissue ectopia. In Prostate pathology (ed. Humphrey PA), pp. 22-23. ASCP, Chicago. 
P.A. Humphrey

Humphrey PA. 2012. Histological variants of prostatic carcinoma and their significance. Histopathology 60: 59-74.

Humphrey PA, Vollmer RT. 1990. Corpora amylacea in adenocarcinoma of the prostate: Prevalence in 100 prostatectomies and clinicopathologic correlations. Surg Pathol 3: $133-141$.

Humphrey PA, Kaleem Z, Swanson PE, Vollmer RT. 1998. Pseudohyperplastic prostatic adenocarcinoma. Am J Surg Pathol 22: 1239-1246.

Humphrey PA, Amin MB, Berney DM, Billis A, Cao D, Cheng L, Delahunt B, Egevad L, Epstein JI, Fine SW, et al. 2016a. Acinar adenocarcinoma. In WHO classification of tumours of the urinary system and male genital organs (ed. Moch H, et al.), pp. 138-161. IARC, Lyon, France.

Humphrey PA, Moch H, Cubilla AL, Ulbright TM, Reuter VE. 2016b. The 2016 WHO classification of tumours of the urinary system and male genital organs-Part B: Prostate and bladder tumours. Eur Urol 70: 106-119.

Iczkowski KA, Ferguson KL, Grier DD, Hossain D, Banerjee SS, McNeal JE, Bostwick DG. 2003. Adenoid cystic/basal cell carcinoma of the prostate: Clinicopathologic findings in 19 cases. Am J Surg Pathol 27: 1523-1529.

Jensen PE, Gardner WAJr, Piserchia PV. 1980. Prostatic crystalloids: Association with adenocarcinoma. Prostate 1: 25-30.

Jiang Z, Woda B, Rock KL, Xu Y, Savas L, Khan A, Pihan G, Cai F, Babcook JS, Rathanaswami P, et al. 2001. P504S: A new molecular marker for the detection of prostate carcinoma. Am J Surg Pathol 25: 1397-1404.

Jiang Z, Li C, Fischer A, Dresser K, Woda BA. 2005. Using an AMACR ( $\mathrm{p} 504 \mathrm{~s}) / 34 \beta E 12 / \mathrm{p} 63$ cocktail for the detection of small focal prostate carcinoma in needle biopsy specimens. Am J Clin Pathol 123: 231-236.

Kaleem Z, Swanson PE, Vollmer RT, Humphrey PA. 1998. Prostatic adenocarcinoma with atrophic features: A study of 202 consecutive, completely embedded radical prostatectomy specimens. Am J Clin Pathol 109: 695-703.

Kim MJ, Divatia MK, Lee JH, Shen S, Miles BJ, Hwang JH, Ayala AG, Ro JY. 2015. Collagenous micronodules in prostate cancer revisited: Are they solely associated with Gleason pattern 3 adenocarcinomas? Int J Clin Exp Pathol 8: $3469-3476$.

Kim J, Davis JW, Klein EA, Magi-Galluzzi C, Lotan Y, Ward JF, Pisters LL, Basler JW, Pettaway CA, Stephenson A, et al. 2016. Tissue effects in a randomized controlled trial of short-term finasteride in early prostate cancer. EBioMedicine 7: 85-93.

Kimura K, Tsuzuki T, Kato M, Saito AM, Sassa N, Ishida R, Hirabayashi H, Yoshino Y, Hattori R, Gotoh M. 2014. Prognostic value of intraductal carcinoma of the prostate in radical prostatectomy specimens. Prostate 74: 68-687.

Koca SB, Yildiz P, Behzatoglu K. 2014. Foamy gland carcinoma in core needle biopsies of the prostate: Clinicopathologic and immunohistochemical study of 56 cases. Ann Diagn Pathol 18: 271-274.

Kryvenko ON, Epstein JI. 2012. Histologic criteria and pitfalls in the diagnosis of lymphovascular invasion in radical prostatectomy specimens. Am J Surg Pathol 36: 1865-1873.

Kweldam CF, Kummerlin IP, Nieboer D, Verhoef EI, Steyerberg EW, van der Kwast TH, Roobol MJ, van Leenders GJ.
2016. Disease-specific survival of patients with invasive cribriform and intraductal prostate cancer at diagnostic biopsy. Mod Pathol 29: 30-636.

Lane BR, Magi-Galluzi C, Reuther AM, Levin HS, Zhou M, Klein EA. 2006. Mucinous adenocarcinoma of the prostate does not confer poor prognosis. Urology 68: 825830.

Lopez-Beltran A, Eble JN, Bostwick DG. 2005. Pleomorphic giant cell carcinoma of the prostate. Arch Pathol Lab Med 129: $683-685$.

Lotan TL, Gumuskaya B, Rahimi H, Hicks JL, Iwata T, Robinson BD, Epstein JI, De Marzo AM. 2013. Cytoplasmic PTEN protein loss distinguishes intraductal carcinoma of the prostate from high-grade prostatic intraepithelial neoplasia. Mod Pathol 26: 587-603.

Magi-Galluzzi C, Zhou M, Reuther AN, Dreicer R, Klein EA. 2007. Neoadjuvant docetaxel treatment for locally advanced prostate cancer: A clinicopathologic study. Cancer 110: $1248-1254$.

Magi-Galluzzi C, Evans AJ, Delahunt B, Epstein JI, Griffins DF, van der Kwast TH, Montironi R, Wheeler TM, Srigley JR, Egevad LL, et al. 2011. International Society of Urological Pathology (ISUP) Consensus Conference of Handling and Staging of Radical Prostatectomy Specimens. Working group 3: Extraprostatic extension, lymphovascular invasion and locally advanced disease. Mod Pathol 24: $26-28$.

Marcus DM, Goodman M, Jani AB, Osunkoya AO, Rossi PJ. 2012. A comprehensive review of incidence and survival in patients with rare histological variants of prostate cancer in the United States from 1973 to 2008. Prostate Cancer Prostatic Dis 15: 283-288.

Markowski MC, Eisenberger MA, Zahurak M, Epstein JI, Paller CJ. 2015. Sarcomatoid carcinoma of the prostate Retrospective review of a case series from the Johns Hopkins Hospital. Urology 86: 539-543.

McNeal JE, Yemoto CE. 1996. Spread of adenocarcinoma within prostate ducts and acini. Am J Surg Pathol 20: 802-814.

McNeal JE, Villers AA, Redwine EA, Freiha EA, Stamey TA. 1990. Histologic differentiation, cancer volume, and pelvic lymph node metastasis in adenocarcinoma of the prostate. Cancer 66: 1225-1233.

McNeal JE, Alroy J, Villers A, Redwine EA, Freiha EA, Stamey TA. 1991. Mucinous differentiation in prostatic adenocarcinoma. Hum Pathol 22: 979-988.

Miettinen M, Wang ZF, Paetau A, Tan SH, Dobi A, Srivastava S, Sesterhenn I. 2011. ERG transcription factor as an immunohistochemical marker for vascular endothelial tumors and prostatic carcinoma. Am J Surg Pathol 35: $432-441$.

Miyai K, Divatia MK, Shen SS, Miles BJ, Ayala AG, Ro JY. 2014. Heterogeneous clinicopathologic features of intraductal carcinoma of the prostate: A comparison bewteen "precursor-like" and "regular-type" lesions. Int J Clin Pathol 7: 2518-2526.

Morais CL, Han JS, Gordetsky J, Nagar MS, Anderson AE, Lee S, Hicks JL, Zhou M, Magi-Galluzzi C, Shah RB, et al. 2015. Utility of PTEN and ERG immunostaining for distinguishing high grade PIN and intraductal carcinoma of the prostate on needle biopsy. Am J Surg Pathol 39: 169-178. 
Morash C, Tey R, Agbassi C, Klotz L, McGowan T, Srigley J, Evans A. 2015. Active surveillance for the management of localized prostate cancer: Guideline recommendations. Can Urol Assoc J 9: 171-178.

Mosse CA, Magi-Galluzzi C, Tsuzuki T, Epstein JI. 2004. The prognostic significance of tertiary Gleason pattern 5 in radical prostatectomy specimens. Am J Surg Pathol 28: 394-398.

Mostofi FK, Sesterhenn IA, Davis CJJr. 1993. A pathologist's view of prostatic carcinoma. Cancer 71: 906-932.

Murphy C, True L, Vakar-Lopez F, Xia J, Gulati R, Montgomery B, Tretiakova M. 2016. A novel system for estimating residual disease and pathologic response to neoadjuvant treatment of prostate cancer. Prostate 76: $1285-1292$.

Nadal R, Schweizer M, Kryvenko ON, Epstein JI, Eisenberger MA. 2014. Small cell carcinoma of the prostate. Nat Rev Urol 11: 213-219.

Nelson RS, Epstein JI. 1996. Prostatic carcinoma with abundant xanthomatous cytoplasm. Foamy gland carcinoma. Am J Surg Pathol 20: 419-426.

O’Brien C, True LD, Higano CS, Radenacher BL, Garzotto M, Beer TM. 2010. Histologic changes associated with neoadjuvant chemotherapy are predictive of nodal metastases in patients with high-risk prostate cancer. Am J Clin Pathol 133: 654-661.

O’Brien BA, Cohen RJ, Wheeler TM, Moorin RE. 2011. A post-radical-prostatectomy nomogram incorporating new pathological variables and interaction terms for improved prognosis. BJU Int 107: 389-395.

Osunkoya AO, Hansel DE, Sun X, Netto GJ, Epstein JI. 2008a. Aberrant diffuse expression of p63 in adenocarcinoma of the prostate on needle biopsy and radical prostatectomy: Report of 21 cases. Am J Surg Pathol 32: 461467.

Osunkoya AO, Nielsen ME, Epstein JI. 2008b. Prognosis of mucinous adenocarcinoma of the prostate treated by radical prostatectomy. A study of 47 cases. Am J Surg Pathol 32: $468-472$.

Pacelli A, Lopez-Beltran A, Egan AJ, Bostwick DG. 1998. Prostatic adenocarcinoma with glomeruloid features. Hum Pathol 29: 543-546.

Pan CC, Potter SR, Partin AW, Epstein JI. 2000. The prognostic significance of tertiary Gleason patterns of higher grade in radical prostatectomy specimens: A proposal to modify the Gleason grading system. Am J Surg Pathol 24: $563-569$.

Park K, Tomlins SA, Mudaliar KM, Chiu YL, Esqueva R, Mehra R, Suleman K, Varambally S, Brenner JC, MacDonald T, et al. 2010. Antibody-based detection of ERG rearrangement-positive prostate cancer. Neoplasia 12: 590-598.

Park K, Chen Z, MacDonald TY, Siddiqui J, Ye H, Erbersdobler A, Shevchuk MM, Robinson BD, Sanda MG, Chinnaiyan AM, et al. 2014. Prostate cancer with Paneth cell-like neuroendocrine differentation has recognizable histomorphology and harbors AURKA gene amplification. Hum Pathol 45: 2136-2143.

Parwani AV, Kronz JD, Genega EM, Gaudin P, Chang S, Epstein JI. 2004. Prostate carcinoma with squamous differentiation: An analysis of 33 cases. Am J Surg Pathol 28: $651-657$.
Parwani AV, Herawi M, Epstein JI. 2006. Pleomorphic giant cell adenocarcinoma of the prostate: Report of 6 cases. Am J Surg Pathol 30: 1254-1259.

Pierorazio PM, Walsh PC, Partin AW, Epstein JI. 2013. Prognostic Gleason grade grouping: Data based on the modified Gleason scoring system. BJU Int 111: 753-760.

Pinto JA, Gonzalez JE, Granadillo MA. 1994. Primary carcinoma of the prostate with diffuse oncocytic change. Histopathology 25: 286-299.

Reuter VE. 1997. Pathological changes in benign and malignant tissue following androgen deprivation therapy. Urology 49: 16-22.

Ro JY, Ayala AG, Ordonez NG, Cartwight JJr, Mackay B. 1986. Intraluminal crystalloids in prostatic adenocarcinoma: Immunohistochemical, electron microscopic, and X-ray microanalytic studies. Cancer 57: 2397-2407.

Ro JY, Grignon DJ, Ayala AG, Fernandez PL, Ordonez NG, Wishnow KI. 1990. Mucinous adenocarcinoma of the prostate: Histochemical and immunohistochemical studies. Hum Pathol 21: 593-600.

Robinson DB, Epstein JI. 2010. Intraductal carcinoma of the prostate without invasive carcinoma on needle biopsy: Emphasis on radical prostatectomy findings. J Urol 184: 1328-1333.

Robinson B, Magi-Galluzi C, Zhou M. 2012. Intraductal carcinoma of the prostate. Arch Pathol Lab Med 136: $418-425$.

Rubin MA, Zhou M, Dhanasekaran SM, Varambally S, Barrette TR, Sanda MG, Pienta KJ, Ghosh D, Chinnaiyan AM. 2002. $\alpha$-Methylacyl coenzyme A racemase as a tissue biomarker for prostate cancer. JAMA 287: 1662-1670.

Rubin MA, Girelli G, Demichelis F. 2016. Genomic correlates to the newly proposed grading prognostic groups for prostate cancer. Eur Urol 69: 557-560.

Ruijter ET, van de Kaa CA, Schalken JA, Debruyne FM, Ruiter DJ. 1996. Histological grade heterogeneity in multifocal prostate cancer. Biological and clinical implications. J Pathol 180: 295-299.

Ryan P, Finelli A, Lawrentschuk N, Fleshner N, Sweet J, Cheung C, van der Kwast T, Evans A. 2012. Prostatic needle biopsies following primary high intensity focused ultrasound (HIFU) therapy for prostatic adenocarcinoma: Histopathological features in tumour and nontumour tissue. J Clin Pathol 65: 729-734.

Sadimin ET, Khani F, Diolombi M, Meliti A, Epstein JI. 2016. Interobserver reproducibility of percent Gleason pattern 4 in prostatic adenocarcinoma on prostate biopsies. Am J Surg Pathol 40: 1686-1692.

Saito S, Iwaki H. 1999. Mucin-producing carcinoma of the prostate: Review of 88 cases. Urology 54: 141-144.

Samaratunga H, Delahunt B, Gianduzzo T, Coughlin G, Duffy D, LeFevre I, Johannsen S, Egevad L, Yaxley J. 2015. The prognostic significance of the 2014 International Society of Urological Pathology (ISUP) grading system for prostate cancer. Pathology 47: 515-519.

Sanati S, Watson MA, Salavaggione AL, Humphrey PA. 2009. Gene expression profiles of ductal versus acinar adenocarcinoma of the prostate. Mod Pathol 22: 12731279.

Sauter G, Steurer S, Clauditz TS, Krech T, Wittmer C, Lutz F, Lennartz M, Janssen T, Hakimi N, Simon R, et al. 2016. 
P.A. Humphrey

Clinical utility of quantitative Gleason grading in prostate biopsies and prostatectomy specimens. Eur Urol 69: 592598.

Scheble VJ, Braun M, Wilbertz T, Stiedl AC, Petersen K, Schilling D, Reischl M, Seitz G, Fend F, Kristiansen G, et al. 2010. ERG rearrangement in small cell prostatic and lung cancer. Histopathology 56: 937-943.

Schelling LA, Williamson SR, Zhang S, Yao JL, Wang M, Huang J, Montironi R, Lopez-Beltran A, Emerson RE, Idrees MT, et al. 2013. Frequent TMPRSS2-ERG rearrangment in prostatic small cell carcinoma detected by fluorescence in situ hybridization: The superiority of fluorescence in situ hybridization over ERG immunohistochemistry. Hum Pathol 44: 2227-2233.

Seipel AH, Delahunt B, Samaratunga H, Egevad L. 2016. Ductal adenocarcinoma of the prostate: Histogenesis, biology and clinicopathological features. Pathology 48: 398-405.

Shannon RL, Ro JY, Grignon DJ, Ordonez NG, Johnson DE, Mackay B, Tetu B, Ayala AG. 1992. Sarcomatoid carcinoma of the prostate. A clinicopathologic study of $12 \mathrm{pa}-$ tients. Cancer 69: 2676-2682.

Shen SS, Lerner SP, Muezzinoglu B, Truong LD, Ameil G, Wheeler TM. 2006. Prostatic involvement by transitional cell carcinoma in patients with bladder cancer and its prognostic significance. Hum Pathol 37: 726-734.

Sheridan T, Herawi M, Epstein JI, Illei PB. 2007. The role of P501S and PSA in the diagnosis of metastatic adenocarcinoma of the prostate. Am J Surg Pathol 31: 1351-1355.

Simper NB, Jones CL, MacLennan GT, Montironi R, Williamson SR, Osunkoya AO, Wang M, Zhang S, Grignon GJ, Eble JN, et al. 2015. Basal cell carcinoma of the prostate is an aggressive tumor with frequent loss of PTEN expression and overexpression of EGFR. Hum Pathol 46: 805-812.

Smith SC, Palanisamy N, Zuhlke KA, Johnson AM, Siddiqui J, Chinnaiyan AM, Kunju LP, Cooney KA, Tomlins SA. 2014. HOXB13 G84E-related familial prostate cancers: A clinical, histologic, and molecular survey. Am J Surg Pathol 38: 615-626.

Spratt DE, Cole AI, Palapattu GS, Weizer AZ, Jackson WC, Montgomery JS, Dess RT, Zhao SG, Lee JY, Wu A, et al 2016a. Independent surgical validation of the new prostate cancer grade-grouping system. BJU Int 118: $763-$ 769.

Spratt DE, Cole AI, Palapattu GS, Weizer AZ, Jackson WC, Montgomery JS, Dess RT, Zhao SG, Lee JY, Wu A, et al. 2016b. Independent validation of the prognostic capacity of the ISUP prostate cancer grade grouping system for radiation treated patients with long-term follow-up Prostate Cancer Prostatic Dis 19: 292-297.

Srigley JR, Delahunt B, Evans AJ. 2012. Therapy-associated effects in the prostate gland. Histopathology 60: 153-165.

Stamey TA, McNeal JE, Yemoto CM, Sigal BM, Johnstone IM. 1999. Biological determinants of cancer progression in men with prostate cancer. JAMA 281: 1395-1400.

Sung MT, Zhang S, Montironi R, MacLennan GT, Mazzucchelli R, Cheng L. 2007. $\alpha$-Methylacyl-CoA racemase $(\mathrm{P} 504 \mathrm{~S}) / 34 \beta \mathrm{E} 12 / \mathrm{p} 63$ triple cocktail stain in prostatic adenocarcinoma after hormonal therapy. Hum Pathol 39: $332-341$.
Suzue K, Montag AG, Tretiakva M, Yang XJ, Sahoo S. 2005. Altered expression of $\alpha$-methylacyl-coenzyme A racemase in prostatic adenocarcinoma following hormone therapy. Am J Clin Pathol 123: 553-561.

Tan HL, Haffner MC, Esopi DM, Vaghasia AM, Giannico GA, Ross HM, Ghosh S, Hicks JL, Zheng Q, Sangoi AR, et al. 2015. Prostate adenocarcinomas aberrantly expressiong p63 are molecularly distinct from usual-type prostatic adenocarcinomas. Mod Pathol 28: 446-456.

Tavora F, Epstein JI. 2008. High-grade prostatic intraepithelial neoplasialike ductal adenocarcinoma of the prostate: A clinicopathologic study of 28 cases. Am J Surg Pathol 32: $1060-1067$.

Têtu B, Ro JY, Ayala AB, Johnson DE, Logothetis CJ, Ordonez NG. 1987. Small cell carcinoma of the prostate. Part 1: A clinicopathologic study of 20 cases. Cancer 59: $1803-$ 1809.

Thorson P, Vollmer RT, Arcangeli C, Keetch DW, Humphrey PA. 1998. Minimal carcinoma in prostate needle biopsy specimens: Diagnostic features and radical prostatectomy follow-up. Mod Pathol 11: 543-551.

Torbenson M, Dhir R, Nangia A, Becich MJ, Kapadia SB. 1998. Prostatic carcinoma with signet ring cells: A clinicopathologic and immunohistochemical analysis of 12 cases, with review of the literature. Mod Pathol 11: $552-559$.

Totten RS, Heinemann MW, Hudson PB, Sproule EE, Stout AP. 1953. Microscopic differential diagnosis of latent carcinoma of prostate. Arch Pathol 55: 131-141.

Tran TT, Sengupta E, Yang XY. 2001. Prostatic foamy gland carcinoma with aggressive behavior. Histologic, immunohistochemical, and ultrastructural analysis. Am J Surg Pathol 25: 618-623.

Van der Kwast T, Al Daoud N, Collette L, Sykes J, Thomas J, Milosevic M, Bristow RG, Van Tienhoven G, Warde P, Mirimanoff RO, et al. 2012. Biopsy diagnosis of intraductal carcinoma is prognostic in intermediate and high risk prostate cancer patients treated by radiotherapy. Eur J Cancer 48: 1318-1325.

Varma M, Lee MW, Tamboli P, Zarbo RJ, Jimenez RE, Salles PG, Amin MB. 2002. Morphologic criteria for the diagnosis of prostatic adenocarcinoma in needle biopsy specimens. A study of 250 consecutive cases in a routine surgical pathology practice. Arch Pathol Lab Med 126: 554-561.

Wang W, Epstein JI. 2008. Small cell carcinoma of the prostate: A morphological an immunohistochemical study of 95 cases. Am J Surg Pathol 32: 65-71.

Warner JN, Nakamura LY, Pacelli A, Humphreys MR, Castle EP. 2010. Primary signet ring carcinoma of the prostate. Mayo Clin Proc 85: 1130-1136.

Warrick JI, Humphrey PA. 2013. Foamy gland carcinoma of the prostate in needle biopsy: Incidence, Gleason grade, and comparative $\alpha$-methylacyl-CoA racemase versus ERG expression. Am J Surg Pathol 37: 17091714.

Watts K, Li J, Magi-Galluzzi C, Zhou M. 2013. Incidence and clinicopathologic characteristics of intraductal carcinoma detected in prostate biopsies: A prospective cohort study. Histopathology 63: 574-579. 
Wobker SE, Epstein JI. 2016. Differential diagnosis of intraductal lesions of the prostate. Am J Surg Pathol 40: e67e82.

Wolf AN, Epstein JI. 2000. Pseudohyperplastic prostatic adenocarcinoma in needle biopsy and simple prostatectomy. Am J Surg Pathol 24: 1039-1046.

Xu J, Stolk JA, Zhang X, Silva SJ, Houghton RL, Matsumura M, Vedvick TS, Leslie KB, Badaro R, Reed SG. 2000. Identification of differentially expressed genes in human prostate cancer using subtraction and microarray. Cancer Res 60: 1677-1682.

Yang XJ, McEntee M, Epstein JI. 1998. Distinction of basaloid carcinoma of the prostate from benign basal cell lesions by using immunohistochemistry for bcl-2 and Ki-67. Hum Pathol 29: 1447-1450.
Yao JL, Madeb R, Bourne P, Lei J, Yang X, Tickoo S, Liu Z, Tan D, Cheng L, Hatem F, et al. 2006. Small cell carcinoma of the prostate: An immunohistochemical study. Am J Surg Pathol 20: 705-712.

Yaskiv O, Cao D, Humphrey PA. 2010. Microcystic adenocarcinoma of the prostate: A variant of pseudohyperplastic and atrophic patterns. Am J Surg Pathol 34: 556561.

Zhou M, Shah R, Shen R, Rubin MA. 2003a. Basal cell cocktail (34ßE12 and p63) improves the detection of basal cells. Am J Surg Pathol 27: 365-371.

Zhou M, Jiang Z, Epstein JI. 2003b. Expression and diagnostic utility of $\alpha$-methylacyl-CoA-racemase (P504S) in foamy gland and pseudohyperplastic prostate cancer. $A m$ J Surg Pathol 27: 772-778. 


\section{$\&_{\mathrm{CSH}}^{\infty} \&$ Cold Spring Harbor

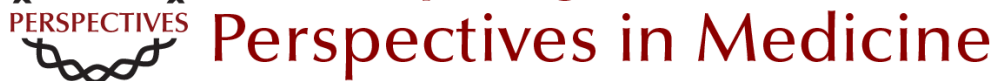

\section{Histopathology of Prostate Cancer}

Peter A. Humphrey

Cold Spring Harb Perspect Med 2017; doi: 10.1101/cshperspect.a030411 originally published online April 7, 2017

\section{Subject Collection Prostate Cancer}

Anatomic and Molecular Imaging in Prostate Cancer

Eric T. Miller, Amirali Salmasi and Robert E. Reiter

The Epidemiology of Prostate Cancer Claire H. Pernar, Ericka M. Ebot, Kathryn M. Wilson, et al.

Prostate Stem Cells and Cancer Stem Cells Jia J. Li and Michael M. Shen

Prostate Cancer Epigenetics: From Basic Mechanisms to Clinical Implications Srinivasan Yegnasubramanian, Angelo M. De Marzo and William G. Nelson

\section{The Genomics of Prostate Cancer: A Historic} Perspective Mark A. Rubin and Francesca Demichelis

Neuroendocrine Differentiation in Prostate

Cancer: Emerging Biology, Models, and Therapies Loredana Puca, Panagiotis J. Vlachostergios and Himisha Beltran

DNA Damage Response in Prostate Cancer Matthew J. Schiewer and Karen E. Knudsen

Transcriptional Regulation in Prostate Cancer David P. Labbé and Myles Brown
New Opportunities for Targeting the Androgen Receptor in Prostate Cancer Margaret M. Centenera, Luke A. Selth, Esmaeil Ebrahimie, et al.

Prostate Cancer Research at the Crossroads Michael M. Shen and Mark A. Rubin

Immunotherapy for Prostate Cancer Nicholas J. Venturini and Charles G. Drake

Molecular Pathology of High-Grade Prostatic Intraepithelial Neoplasia: Challenges and Opportunities Levent Trabzonlu, Ibrahim Kulac, Qizhi Zheng, et al.

Metastases in Prostate Cancer Federico La Manna, Sofia Karkampouna, Eugenio Zoni, et al.

Genetically Engineered Mouse Models of Prostate Cancer in the Postgenomic Era Juan M. Arriaga and Cory Abate-Shen

Molecular Biomarkers in the Clinical Management of Prostate Cancer Aaron M. Udager and Scott A. Tomlins

Metabolic Vulnerabilities of Prostate Cancer: Diagnostic and Therapeutic Opportunities Giorgia Zadra and Massimo Loda

For additional articles in this collection, see http://perspectivesinmedicine.cshlp.org/cgi/collection/ 